\title{
Facilitation and competition in coastal dunes: meta-analysis of determinants of plant interactions
}

Facilitação e competição em planícies costeiras: meta-análise de fatores determinantes de interações entre plantas

Luanne Caires da Cruz Souza

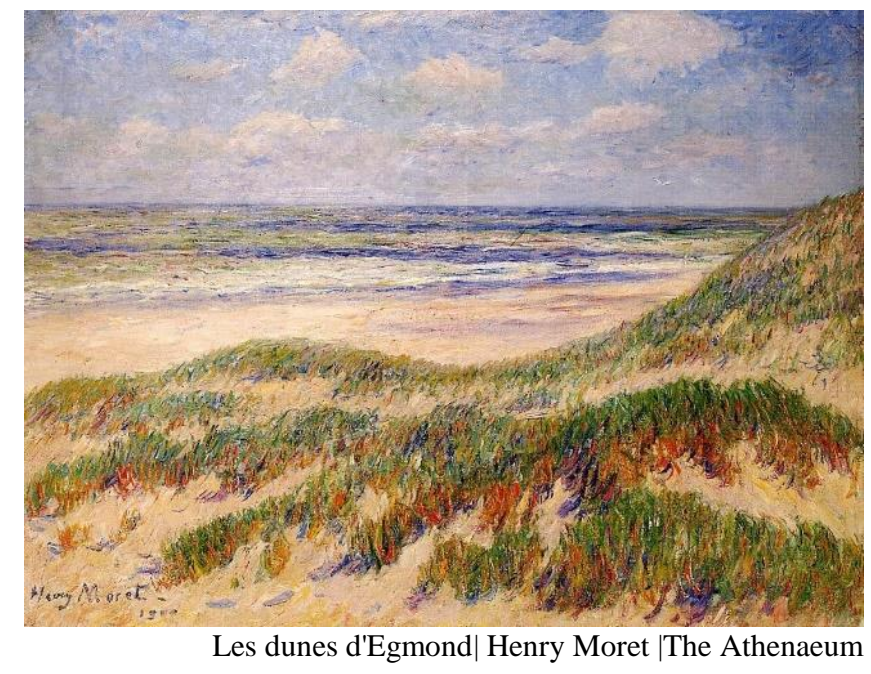

SÃO PAULO

2018 


\author{
UNIVERSIDADE DE SÃO PAULO \\ INSTITUTO DE BIOCIÊNCIAS \\ Programa de Pós-GRAdUAÇÃo EM ECOLOGIA
}

\title{
Facilitation and competition in coastal dunes: meta-analysis of determinants of plant interactions
}

Facilitação e competição em planícies costeiras: meta-análise de fatores determinantes de interações entre plantas

\section{Luanne Caires da Cruz Souza}

Dissertação apresentada ao Instituto de Biociências da Universidade de São Paulo, para a obtenção de Título de Mestre em Ciências, na área de Ecologia.

Orientadora: Profa. Dra. Camila T. Castanho Coorientadora: Profa. Dra. Adriana M. Z. Martini 


\section{Ficha CATAlográfica}

\section{Caires, Luanne}

Facilitation and competition in coastal dunes: meta-analysis of determinants of plant interactions / Luanne Caires da Cruz Souza; advisor Camila de Toledo Castanho - São Paulo, 2018.

Versão em português: Facilitação e competição em planícies costeiras: meta-análise de fatores determinantes de interações entre plantas / Luanne Caires da Cruz Souza; orientadora Camila de Toledo Castanho - São Paulo, 2018.

$62 p$.

Dissertação (Mestrado) - Instituto de Biociências da Universidade de São Paulo. Departamento de Ecologia.

1. Positive interactions 2. Negative interactions 3. Environmental stress 4. Plant life form and ontogeny 5. Sandy coastal plains 6. Synthesis. I. Universidade de São Paulo. Instituto de Biociências. Departamento de Ecologia.

Versão em português: 1. Interações positivas 2. Interações negativas 3. Severidade ambiental 4. Forma de vida e ontogenia de plantas 5. Dunas costeiras 6. Síntese. I. Universidade de São Paulo. Instituto de Biociências. Departamento de Ecologia.

\section{COMISSÃO JULGADORA}

$\operatorname{Prof}(a) . \operatorname{Dr}(a)$.

Prof(a). Dr(a).

$\operatorname{Prof}(\mathrm{a}) . \operatorname{Dr}(\mathrm{a})$.

Profa. Dra. Camila de Toledo Castanho

Orientadora 
A todas as pessoas que se esforçam para que a pós-graduação vá além da produção de artigos. 
"O ser humano nasceu para aprender, aprender tanto quanto a vida lhe permita."

JOÃO GUIMARÃES ROSA. 


\section{AgradeCimentos / ACKNOWLEDGMENTS}

À Coordenação de Aperfeiçoamento de Pessoal de Nível Superior (CAPES) pelo financiamento necessário para o desenvolvimento deste projeto de mestrado.

Ao Programa de Pós-graduação em Ecologia, ao Instituto de Biociências e à Universidade de São Paulo, pelo apoio estrutural e pela formação intelectual durante o curso. Especialmente à Comissão Coordenadora do Programa pela constante preocupação com o desenvolvimento dos alunos e por estar aberta à nossa participação na construção de um Programa melhor; e às secretárias, Vera e Shirlene, por serem modelos de eficiência e por estarem sempre dispostas a esclarecer dúvidas e a ajudar no que for preciso.

Às minhas orientadoras, Dri e Cam, por serem as melhores orientadoras que eu poderia ter. Obrigada pelos inúmeros ensinamentos, por todo o apoio, compreensão, paciência, confiança e amizade, por me incentivarem a superar os (muitos) momentos difíceis durante o mestrado, por acreditarem na minha capacidade apesar desses momentos e por sempre me lembrarem da beleza e das alegrias da construção do conhecimento. Trabalhar com vocês foi sensacional.

Aos membros do meu comitê de acompanhamento, Bruno Rosado e Leandro Duarte, pelas valiosas sugestões e críticas ao projeto e por embacarem com bom humor em todas as mudanças ao longo do processo.

A todas as pessoas que me ajudaram com a análise de dados, especialmente ao Edu, pelos ótimos ensinamentos durante a disciplina sobre meta-análise e por todas as dicas posteriores; e à Melina e ao Danilo, pelas discussões sobre modelos e outros detalhes estatísticos. Aprendi muito com vocês.

Aos técnicos do Labtrop, pela ótima convivência e pelo apoio prático ao longo do desenvolvimento do trabalho. Especialmente à Natália pela ajuda com a coleta de dados de atributos funcionais que, embora não tenham entrado na dissertação, serão fundamentais para projetos futuros; e à Rai, pelo imenso carinho, preocupação e preciosos conselhos.

Às demais pessoas que, direta ou indiretamente, me ajudaram e me ensinaram a ser uma cientista e uma pessoa melhor. Especialmente à Renata e ao Paulo Inácio, professores com cujo incentivo sempre pude contar e que marcaram minha formação por sua dedicação à ciência e aos alunos.

Às amigas e aos amigos do Labtrop, pelo companheirismo, risadas, discussões ao mesmo tempo divertidas e produtivas, e pelos memoráveis eventos de coexistência mediada por cerveja. 
Especialmente à Luisa, por ter me acolhido enquanto o mestrado era só uma ideia e pela bela amizade desenvolvida no dia-a-dia do laboratório e fora dele.

Às amigas e aos amigos do Café Existencial e da Comissão Proex, pelo maravilhoso trabalho em equipe, pelo apoio na vida acadêmica e fora dela e por me ajudarem a ampliar minha formação para além dos manuscritos científicos. Especialmente ao Renato (Natcho), por ter sido um mentor e um modelo em muitos momentos, embora talvez não saiba disso ainda. Trabalhar com vocês foi uma das melhores experiências da minha pós-graduação.

Às amigas e aos amigos do curso de pós-graduação, pelos laços de amizade e por compartilharem as belezas e dificuldades da pós, tornando esse caminho muito mais leve, rico e feliz. Especialmente a Raquel, Pelinson, Pietro, Louise, Lygia, Cirrose, Vini, Mila e Morma, pelo afeto e companheirismo que extrapola as fronteiras acadêmicas.

Às amigas e aos amigos espalhados pelo mundo que, mesmo seguindo caminhos distintos, estão sempre presentes na minha vida. Obrigada pelo conforto e alegria que a amizade de vocês me traz.

Às meninas da Eiras (Duda, Dani e Ju), por terem aberto as portas da casa e do coração para me receber na fase pingue-pongue do mestrado, por fazerem com que eu me sentisse em casa, pelo cuidado e pelo carinho. Especialmente à Duda, pela amizade que vem desde a época de graduação. Desejo que esta fase de vocês em São Paulo seja uma experiência maravilhosa!

Ao pessoal da Uairigatô (Lucas, Aline, Nádia, Du e Lelê), por terem feito a casa de vocês ser também a minha casa nestes últimos meses, por todo o amor, diversão, cumplicidade e generosidade. Vocês foram uma família para mim nesta cidade desafiadora e incrível.

Ao Lucas, mais uma vez, por ser um dos maiores presentes que São Paulo e a Ecologia me deram com essa amizade tão sincera e bonita. Obrigada especialmente pelo cuidado na fase final do mestrado, pela companhia e ajuda nas madrugadas de trabalho e por amenizar o cansaço e o estresse com seu jeito alegre e mineiro de ser.

Ao Rodolfo, pelo amor e parceria nas aventuras do mestrado e fora dele, pelas discussões sobre a vida, o universo e tudo mais e por gostar bem mais do R do que eu, me ajudando imensamente com alguns dos códigos e com as figuras. Que venham as próximas aventuras para encararmos juntos!

À minha família, pelo amor incondicional, por ser sempre um porto seguro e por apoiar meus sonhos. Sem vocês nada disso seria possível. 


\section{CONTENTS}

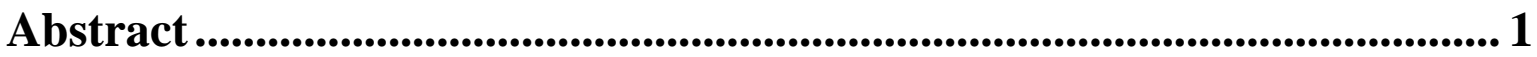

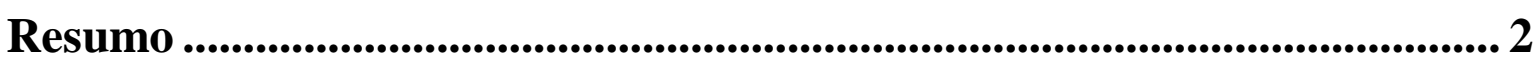

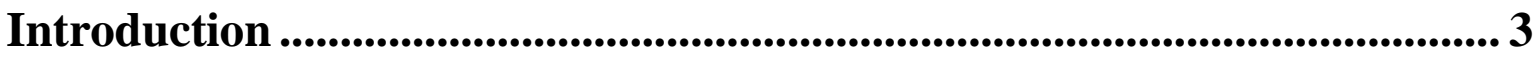

Material and methods ..................................................................................... 7

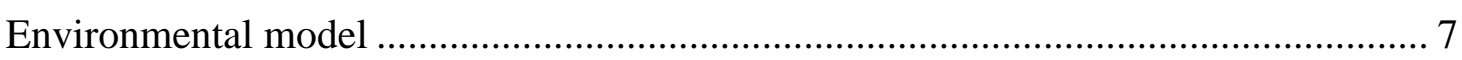

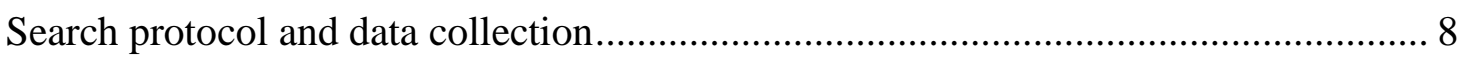

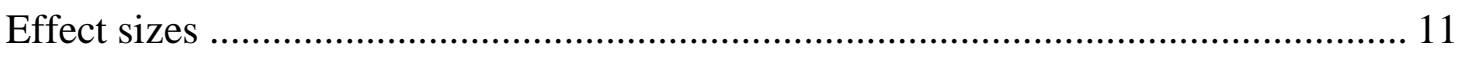

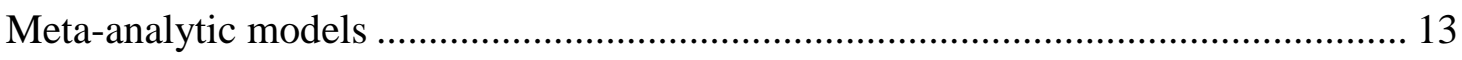

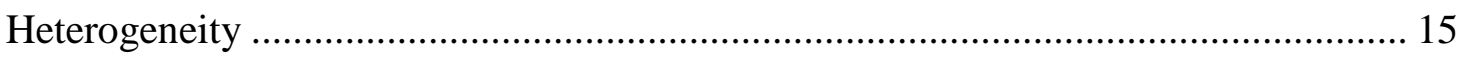

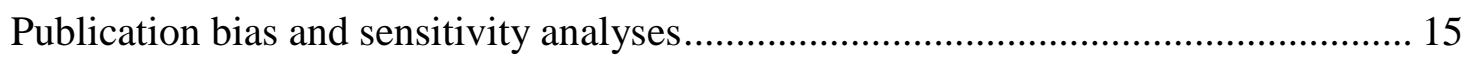

Results......................................................................................................................... 16

General characterization of data set ................................................................... 16

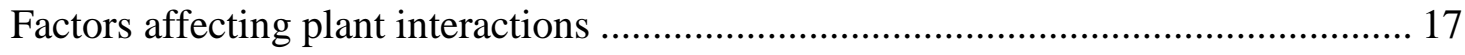

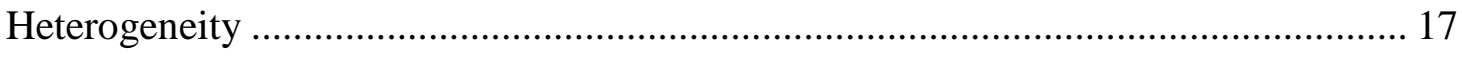

Publication bias and sensitivity ………………………….................................... 18

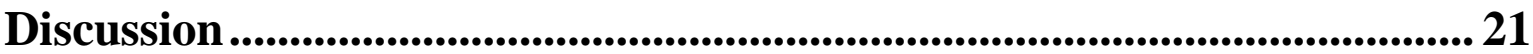

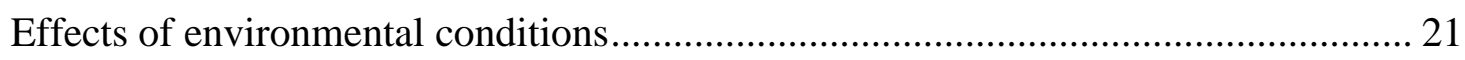

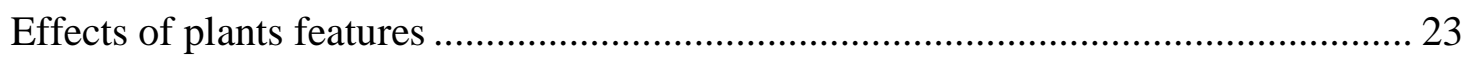

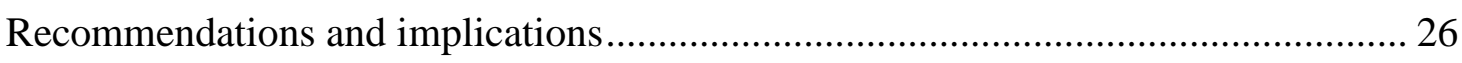

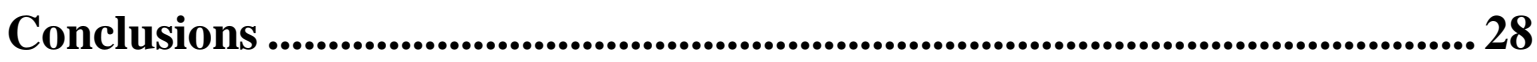

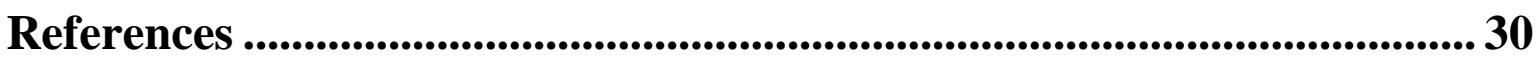

Supporting Information.............................................................................................. 40 


\section{AbStract}

Plants established next to other plants may have their performance positively or negatively affected by their neighbors, which characterizes interactions of facilitation and competiton, respectively. Facilitation and competition, however, may occur simultaneously and understanding which one predominates in pairwise interactions under different ecological contexts is important to comprehend the structure of plant communities. According to the stressgradient hypothesis (SGH), facilitation is expected to prevail in more severe environments, but the outcome of interactions may change depending on features of interacting individuals, such as life form and ontogenetic stages. As harsh conditions and high diversity of plant life-forms are characteristic of coastal dunes, the amount of studies about plant interactions has been rapidly increasing in these ecosystems, with apparent divergent conclusions. However, until now, there is not a systematic and quantitative synthesis about the factors affecting the net outcome of facilitation and competition in these ecosystems. We conducted a meta-analysis to investigate the effects of environmental stress and the simultaneous influence of plant life form and ontogenetic stage on the outcome of facilitation and competition in coastal dunes around the world. We used four performance measures to estimate the outcome of interactions: abundance, survival, growth, and reproduction. Contrary to what was expected by SGH, we found that negative impacts of neighbors on plant reproduction increase towards more arid conditions, but this effect was not observed for other performance measures. Our results also indicate that woody neighbors facilitate the survival of woody seedlings and the reproduction of herbs, while herbaceous neighbors facilitate the growth of other herbaceous plants. Overall, the outcome of plant interactions in coastal dunes depends on the performance variable measured and on both environmental conditions and plant features, indicating an interaction between these factors. Such interaction and different mechanisms underlying facilitation and competition should be more investigated in the future. The global scale of our meta-analysis supports generalization of important processes of succession and conservation in coastal dunes. Benefits of woody neighbors to the survival of woody seedlings corroborate the concept of successional feedbacks in the beach-inland physiognomic gradient, and our results reinforce the use of nurse plants in coastal dunes as a valuable tool to restoration of these endangered ecoystems.

Key words: positive interactions, negative interactions, environmental stress, plant life form and ontogeny, sandy coastal plains, synthesis. 


\section{RESUMO}

Plantas estabelecidas nas proximidades de outras plantas podem ter sua performance afetada positiva ou negativamente por seus vizinhos, caracterizando, respectivamente, interações de facilitação e competição. Considerando que ambas as interações podem ocorrer de forma simultânea, compreender o predomínio de cada uma delas em diferentes contextos ecológicos é fundamental para o entendimento da estrutura de comunidades vegetais. De acordo com a hipótese do gradiente de estresse (HGE), a facilitação tende a predominar em ambientes mais severos, mas o balanço das interações depende ainda das características dos indivíduos envolvidos, como forma de vida e estágio ontogenético. Como condições ambientais severas e alta diversidade de formas de vida vegetais são características de planícies costeiras, o número de estudos investigando interações entre plantas tem aumentado rapidamente nesses ambientes, com conclusões aparentemente divergentes. No entanto, ainda não há uma síntese sistemática e quantitativa dos fatores que afetam o balanço entre facilitação e competição nesses ecossistemas. Nós realizamos uma meta-análise em escala global para investigar os efeitos do estresse ambiental e a influência simultânea da forma de vida e do estágio ontogenético das plantas sobre o balanço entre facilitação e competição em planícies costeiras. Utilizamos quatro variáveis de performance para estimar o balanço de interações: abundância, sobrevivência, crescimento e reprodução. Ao contrário do predito pela HGE, encontramos que impactos negativos de plantas vizinhas sobre a reprodução de outras plantas aumentam com a aridez do ambiente, mas que esse efeito não é observado para outras variáveis de performance. Nossos resultados também mostram que vizinhos lenhosos facilitam a sobrevivência de plântulas lenhosas e a reprodução de plantas herbáceas, enquanto vizinhos herbáceos facilitam o crescimento de outras herbáceas. De modo geral, o balanço das interações depende da variável de performance medida e tanto de condições ambientais quanto de características das plantas, indicando que esses fatores interagem. Tal interação e os diferentes mecanismos subjacentes à facilitação e à competição devem ser melhor investigados no futuro. A maior sobrevivência de plântulas lenhosas na presença de vizinhos lenhosos corrobora a ideia de retroalimentação positiva no processo sucessional que caracteriza o gradiente fisionômico da praia ao interior. Nossos resultados também reforçam o potencial do uso de plantas-berçários como ferramenta para restauração de planícies costeiras degradadas.

Palavras-chaves: interações positivas, interações negativas, severidade ambiental, forma de vida e ontogenia de plantas, dunas costeiras, síntese. 


\section{INTRODUCTION}

Interactions among plants largely determine the structure and dynamic of plant communities (Lortie 2004, Wright et al. 2014). Two plant-plant interactions extensively investigated are competition and facilitation, classified according to the effect that an individual has on the performance of surrounding plants. Competition in plant communities is primarily related to the depletion of resources (e.g. water, nutrients, light and space) and to interference competition (e.g. allelopathy) and leads to decreased performance at individual plants (Berger et al. 2008, Craine \& Dybzinski 2013, Wright et al. 2014). On the other side, facilitation enhances plant performance due to changes in abiotic conditions (e.g. reduced direct solar irradiance, and air and soil temperatures), improvement in soil resources availability or indirect interactions with other organisms (such as protection against herbivores, attraction of pollinators and dispersers) (Brooker et al. 2008, Bonanomi et al. 2011).

Although facilitation and competition have opposite effects on plant performance, both may occur simultaneously (Holzapfel \& Mahall 1999, Maestre et al. 2003). Therefore, the net effect that a plant has on the surrounding individuals is the result of facilitation/competition balance, which varies in time and space (Callaway et al. 2002). Some of the factors that influence this complex balance are environmental stress (Bertness \& Callaway 1994, He et al. 2013), life form and ontogenetic stage of the plant individuals (Miriti 2006, Armas \& Pugnaire 2009, Gómez-Aparicio 2009, Castanho et al. 2012), their ecological strategies (Maestre et al. 2009) and phylogenetic relationships (Verdú et al. 2012, Pistón et al. 2015, Zhang et al. 2016).

The effect of environmental conditions on the outcome of plant interaction has been topic of debate during the last decades. The stress gradient hypothesis ( $\mathrm{SGH}$ ), proposed by Bertness and Callaway (1994), predicts a positive linear relationship between environmental stress level and the frequency or importance of facilitation. According to this hypothesis, harsh abiotic conditions restrict resource acquisition by plants and the presence of a neighbor may 
reduce the stress level under its canopy, overcoming the negative effects of resource competition (Bertness \& Callaway 1994). On the other hand, competition prevails in pairwise interactions in environmental with less harsh conditions (Bertness \& Callaway 1994, Brooker \& Callaghan 1998). Although several studies have corroborated the predictions of SGH (Callaway et al. 2002, Gómez-Aparicio et al. 2004, Holzapfel et al. 2006, He et al. 2013), there are some controversies about the shape of the relationship between the outcome of interactions and environmental conditions (Maestre \& Cortina 2004, Maestre et al. 2009, Homlgren \& Scheffer 2010, Soliveres \& Maestre 2014, Soliveres et al. 2015). Nevertheless, there is an apparent consensus about the importance of environmental conditions for the results of plant interactions.

To access the outcome of plant interactions, the effects that a specific plant (neighbor) have on a focal plant (target) are estimated. However, such effects depend on the combination of life forms of both neighbors and targets. In general, herbaceous neighbors tend to negatively affect the performance of target plants probably because their high root/shoot ratios promote strong competition for soil resources (Gómez-Aparicio 2009, He et al. 2013). Shrubs and trees, on the other hand, have positive effects on target plants, probably due to height and canopy architecture that promotes shade and microclimatic amelioration under its canopies, especially important in harsh environments (Gómez-Aparicio 2009, Bonanomi 2011, He et al. 2013).

Despite this general pattern, features of target individuals can also change the expected outcome. Both life forms and ontogenetic stages can affect their stress tolerance and competitive ability (Reisman-Berman 2007, Quero et al. 2008, Gómez-Aparicio 2009). Woody species, especially during early ontogenetic stages, are more vulnerable to high solar irradiance, elevated temperatures and low air humidity, typical conditions of relatively open environments, such as the harsh environments cited above (Sage 2017). This is probably because seedlings have less stored carbon and less access to soil water resources compared to larger plants 
(Niinemets 2010) and thus have lower tolerance to environmental stress. Hence, seedlings of woody species tend to perform better in association with other plants (Bateman et al. 2018). Benefits to seedlings, however, tend to be larger with woody neighbors because herbaceous neighbors have massive superficial radicular system that strongly overlaps seedlings radicular systems (February et al. 2013, Cipriotti et al. 2014). Even though woody seedling can be benefited by other woody individuals, this effect may disappear along the ontogenetic development. In more advanced ontogenetic stages the requirements of individuals may change, e.g. seedlings benefited by shading may turn into adults whose growth is undermined in shade conditions (Reisman-Berman 2007, Quero et al. 2008). Increased resource uptake as plants grow is another explanation for why competition may increase and, hence, the relative effect of facilitation may decrease along plant ontogeny (Verdú et al. 2004, Miriti 2006, Schiffers \& Tielbörger 2006, Armas \& Pugnaire 2009). Contrary to woody species, herbaceous target plants, especially graminoids, perform better under high light availability (Guido et al. 2017, Sage 2017) and can be negatively affected by shading conditions under shrubs and trees (Gómez-Aparicio 2009, Castanho et al. 2012, but see Dohn et al. 2013). Responses of different ontogenetic stages of herbs are less known because of difficulties in separating adults and juveniles in the field.

Net outcome of interaction also depends on the choice of performance estimator (Foster 2002, Franks 2003, Gómez-Aparicio 2009, Castanho \& Prado 2014, Bertoncello et al. 2016). This variation is due to differences in requirements for abundance, survival, growth, and reproduction (Escós et al. 2000, Hastwell \& Facelli 2003, Maestre et al. 2005). Plant abundance, for instance, may be directly affected by dispersers and seed predators (Traveset $e t$ al. 2001), which are not directly related to other performance estimators, such as growth and reproduction. Furthermore, environmental conditions that favor establishment may differ from those maximizing increment in height or biomass. While the shade provided by neighbors may 
reduce direct solar irradiance and increase plant survival, reduction in light conditions may limit the potential carbon gain and investment in reproductive structures (Aranda et al. 2007, Holmgren 2012). Therefore, the presence of a neighbor may increase seedlings survival but may not affect growth or may affect it in a negative way (Foster 2002; Franks 2003; GómezAparício 2009, Castanho \& Prado 2014).

In the last years, the number of studies investigating factors that affect the outcome of plant interactions in different environments has increased (Michalet \& Pugnaire 2016). One of the environments where the study of plant interactions has received particular attention is coastal dunes (Castanho et al. 2015a). Several factors potentially limit plant performance in coastal plains, such as high temperatures, exposure to wind, high salinity, sand burial, high soil water drainage, low nutrient availability and concentration of nutrients in superficial soil layers (Wilson \& Sykes 1999, Lane et al. 2008). Plants can ameliorate these harsh conditions in their neighborhood and, in fact, several studies have found better performance of plants established near other plants compared to isolated ones (Shumway 2000, Joy \& Young 2002, Martínez 2003, Franks 2003, Forey et al. 2009, Castanho \& Prado 2014, Castanho et al. 2015b). However, evidences of competition between plants in coastal dunes have also been found (Litcher 2000, Cheplick 2005, Forey et al. 2009), suggesting the predominance of facilitation or competition depends on environmental and ecological context. Due to high variability of environmental severity and plant features, such as neighbor and target life forms, coastal dunes present a great opportunity to investigate potential causes of divergence among studies. In order to do so, quantitative syntheses, such as meta-analyses, are helpful tools because they permit to summarize current literature, provide general estimates to an effect of interest, test the importance of ecological factors and identify research gaps (Nakagawa et al. 2017).

Our aim is to investigate which is the predominant interaction between plants in sandy coastal plains and to identify which factors determine the net outcome of interaction in this 
environment in a global scale. We address two main questions: 1) how the outcome of plant interactions varies with environmental stress? and 2) how the life form and ontogenetic stage of interacting plants affect the outcome of interactions. We hypothesize that: 1) in general, net outcome of interaction will become more positive as environmental conditions become harsher; 2) when the neighbor is a woody species, net outcome of interaction will be positive if the target is a woody seedling, neutral or negative if the target is a woody adult, and negative if target is herbaceous, independent of target ontogenetic stage; when the neighbor is a herb, net outcome of interaction will be negative for woody seedlings, neutral for woody adults, negative for herbaceous seedlings and neutral or negative for herbaceous adults. Such hypothesized outcomes might vary with the performance estimator used.

\section{MATERIAL AND METHODS}

\section{Environmental model}

Coastal dunes are sandy coastal plains formed by marine deposits and shaped by sand deposition, accretion and erosion (Psuty 2008). They are characterized by a beach-inland gradient, with primary dunes composed by sand blown directly from active beach and submitted to nearshore process, and secondary dunes developed further inland after modification of primary dunes (Psuty 2008). Harsh physical conditions, such as sand movement, salt spray and low soil moisture and nutrient availability, lead to a zonation pattern in the vegetation of coastal dunes (Miller et al. 2010, Bitton \& Hesp 2013).

In the foredunes, under greater influence of the ocean, there is a predominance of psammophytes and herbaceous species, frequently grasses, that are more resistant to sand burial and salt spray. They bind sand, stabilize substrate, and trap seeds, favoring the development of dune succession (Oosting \& Billings 1942, Fenu et al. 2013). In intermediate parts of beachinland gradient, vegetation is characterized by an open scrubland, with higher plant diversity, 
soil moisture and nutrient availability (Fenu et al. 2013). In the back dunes, with milder abiotic conditions, unvegetated free spaces are rare, and beach forests are dominate by woody shrubs and trees (Lichter 2000, Cusseddu 2016).

Since coastal dunes are spread around the world, in a wide range of latitudes and climates, the general environmental conditions greatly vary among coastal areas. Such variability, associated to changes in species composition and predominant plant life forms, make sandy coastal plains an interesting ecosystem to test hypotheses about the outcome of plant-plant interactions.

\section{Search protocol and data collection}

We screened the literature to find studies that explicitly tested plant-plant interactions in sandy coastal plains. We used the core collection of ISI Web of Knowledge and the following combination of terms: ((dune* OR restinga OR coastal sand* vegetation) AND (facilitation OR positive interaction* OR competition OR negative interaction*) AND (plant* OR tree* OR shrub* OR herb*)). Asterisks represent any letters and were used to include the plural or other possible complements of each term. The survey was last updated in May 26, 2017 and led to 406 publications that were examined for suitability for the meta-analysis (Fig. 1).

For selection based on title and abstract, we included all publications that: 1) indicated the study was a test of plant-plant interactions; 2) did not indicate that it was conducted in environments other than coastal plain; 3) presented any measure of plant performance (abundance, survival, growth, reproduction, occurrence and emergence). If the third criterion were not met, the publication had to present in title or abstract some indication that plant performance was assessed, and that these data could be find in the complete text. 
After this first selection, we proceeded to the full reading of remaining studies $(n=91)$. The inclusion criteria at this step were: 1) study area located at sandy coastal plain; 2) sampling design with control (target plant in absence of neighbors plants) and treatment (target plants in presence of neighbors); 3) study conducted in natural field conditions; 4) study with species (native or exotic) that naturally occur in the study area; 5) study area without signs of recent great disturbances; 6) available data of plant performance, and 7) available data to calculate effect size (see details in section "Effect sizes"). After full reading, we selected 31 studies as eligible for meta-analysis.

We identified each study with a unique number and extracted the following data from text and supplementary materials: geographic coordinates of the study area; part of the coastal gradient where the study was conducted (primary dunes, scrub, back dunes); identity of neighbor and target plant species; life form of neighbor and target species (forb, grass, shrub, tree, other); ontogenetic stage of target plants (seedling, juvenile, adult, several); theoretical variable of performance (emergence, abundance, survival, growth, reproduction or occurrence); operational variable of performance (e.g., height, diameter or biomass for growth); study type (observational or experimental, both in field condition); sample size, and statistics useful for effect size calculation (proportions of success and failures in control and treatment for categorical data, and mean and error measures of control and treatment groups for continuous data).

To represent environmental severity, we used the global aridity index (GAI) of The Consortium for Spatial Information (CGIAR-CSI) (http://ww.cgiar-csi.org/data/global-aridity -and-pet-database; Zomer et al. 2007, 2008). The index combines mean annual precipitation and mean annual evapotranspiration, averaged for the 1950-2000 period, and is available with the resolution of 30 arc seconds (approximately $1 \mathrm{~km}$ at the equator). Higher values of GAI indicate more humid conditions. If the study did not report geographical coordinates or if the 
coordinates reported corresponded to points in ocean in GAI database, we got geographical coordinates for the study site in Google Earth. Regarding to plant features, we used data from Plants of the World platform (http://powo.science.kew.org/; Kew Royal Botanic Gardens 2017) to access information about botanical families and species life forms when they were not provided in the studies. If the study was conducted in Brazil, we also used as source the REFLORA platform (http://reflora.jbrj.gov.br; Reflora 2017).

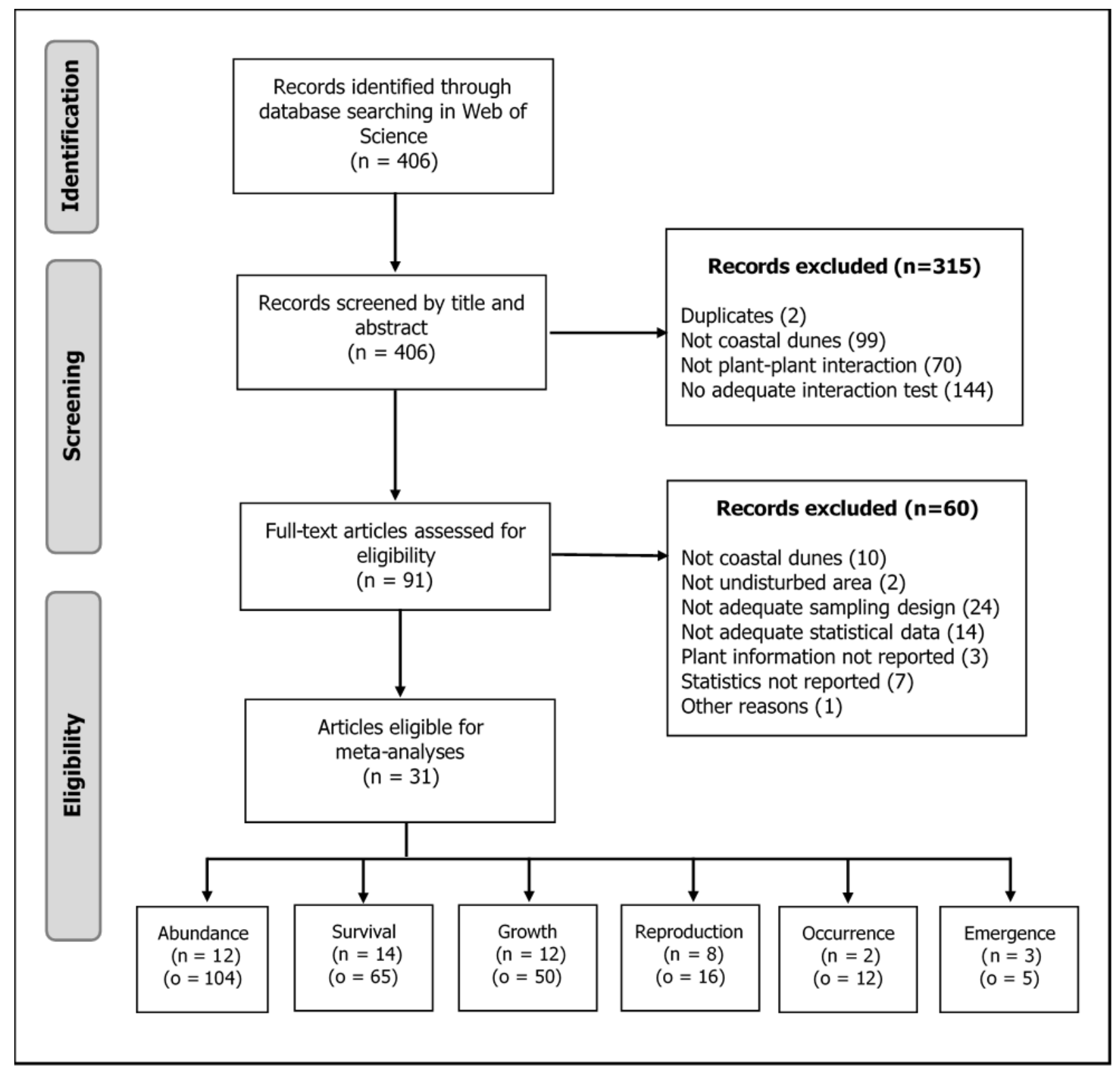

Figure 1. Prisma flow diagrama depicting search, screening and eligibility protocols in determining the studies effective included in meta-analysis. N: number of publications and o: number of outcomes. 
If the same study tested different combinations of neighbor and target species, different ontogenetic stages or included different sites, we considered each outcome as a different observation with posterior consideration of dependence between data (Koricheva et al. 2013). When the study presented data from different points on the same zone of dune gradient (different points in foredunes, for instance), we used only data from the intermediate part of the zone in order to get the most representative point of that area. If the study used different operational variables for the same theoretical variable of performance, we selected only one of them. For abundance, we prioritize plant density, followed by relative plant density and plant cover. For growth, the order of priority was total biomass, aboveground biomass, increment in canopy area, plant height and belowground biomass. For reproduction, the priority was total number of flowers or fruits, number of spikelets for plants, flowering stem densities and number of branches with flowers.

In cases with additional treatments, such as nutrient and water addition or herbivore exclusion, we used only the results from level with no addition or exclusion, to approximate field natural conditions. If repeated measures were taken from the same experiment, we used only the results reported at the end of the experiment to avoid pseudoreplication. Furthermore, in multiyear independent experiments, we used data from multiple years only if the plant individuals considered in the study were different from one year to another. If the same plant individuals were considered, we used data from the last year. When the required data to calculate effect sizes were reported only in graphical form, we extracted it using Graph Grabber 2.0 software (Quintessa 2017). When data and statistics were not available in publication, we contacted authors to get the missing information.

\section{Effect sizes}

We calculated the effect size for each outcome and separated them by performance variable (Table S1). Effect size, the basic unit of meta-analysis, reflects the magnitude of effect 
that treatment has relative to control (Borenstein et al. 2009). In general, the studies report results in two ways: as means and error measures and as contingency tables, depending on the performance variable and the design of data collection. For the studies that reported data as means, error measures and sample size of control and treatment groups, we calculated the standardized mean difference (Hedges' d) (Koricheva et al. 2013). Values of Hedges' d higher than 0 indicate that neighbors have a positive effect on performance of targets (facilitation), while values lower than 0 indicate negative effects of neighbors (competition). We calculated Hedges' d for all outcomes of abundance, growth and reproduction (Table 1).

When the publication reported data as contingency tables, we calculated the natural logarithm of odds ratio $(\ln (\mathrm{OR}))$ as the effect size. The odds ratio is the ratio of two relative probabilities: the probability of success relative to failure in the group with neighbor (treatment) and the probability of success relative to failure in the group without neighbors (control) (Koricheva et al. 2013). Similarly to Hedges' d, positive values of $\ln (\mathrm{OR})$ indicate facilitation and negative values indicate competition. Original studies reported survival in two ways: as means and error measures and as contingency tables. We chose Hedges' d as the final effect size because it demanded the least number of effects size transformation (Table 1). For survival data originally reported as contingency table (28 outcomes), we calculated Hedges' d values converted from odds ratio (Borestein et al. 2009). We assumed a normal distribution of data in the conversion.

All effect sizes were calculated using the function escalc of the package metafor (Viechtbauer 2010) in R environment (R Development Core Team 2018). We calculated effect sizes only for performance variables with more than five remaining outcomes derived from three or more articles, after the exclusions described in the previous section. This conservative approach is an attempt to minimize potential false interpretations based on small sample sizes. Since we had only three outcomes on the emergence dataset and outcomes from only two 
publications on the occurrence dataset, we excluded these performance variables from further analysis.

Table 1. Performance variables, examples of operational variables and type of effect sizes. Asterisks indicate which data included effect size transformation.

\begin{tabular}{llcc}
\hline Performance & Example of operational variable & Type of response & Effect size \\
\hline Abundance & $\begin{array}{l}\text { Density, cover density } \\
\text { Mean number of survivors or number } \\
\text { of survivals and dead plants }\end{array}$ & $\begin{array}{l}\text { Continuous } \\
\text { Continuous/ } \\
\text { categorical }\end{array}$ & Hedges'd \\
Growth & Hedges'd* \\
Reproduction & Flower, fruit or seed production & Continuous & Hedges'd \\
\hline
\end{tabular}

\section{Meta-analytic models}

To determine the net outcome of interactions for each performance variable, we used hierarchical models, which permit the specification of nested groups and, therefore, account for dependences in the dataset. To investigate the effect of environmental stress, we performed a hierarchical model with effect sizes as response variable, global aridity index (GAI) as fixed predictor and study identity, neighbor species identity and target species identity as random factors. The inclusion of these random factors aims to control for dependence of data provided by the same studies or by different studies that used the same species. Our prediction for this model is that values of Hedges' $d$ will become more positive with the increase in values of GAI.

To investigate the effect of plant features on the net outcome of interactions, we performed another hierarchical model with effect sizes as response variable, neighbor life form, target life form, target ontogenetic stage and their interactions as fixed predictors and study identity, neighbor species identity and target species identity as random factors. In these models, each categorical variable has two levels. For life forms, the levels are herb (forbs and/or grasses) and woody (sub-shrubs, shrubs and/or trees) and for ontogenetic stage, the levels are seedling 
and not seedling (juveniles and/or adults). We excluded all outcomes from mosses and climbers due to small number of studies investigating these life forms. We also excluded all outcomes from which the study did not specify the identity or the life form and ontogenetic stages of interacting individuals, and for which we could not find enough information about these features in the databases used. Since for the abundance data set most outcomes referred to targets with undescribed ontogenetic stages, we analyzed only the effects of life forms. For analysis of reproduction, only adult plants are considered and, therefore, ontogenetic stage is not a predictor variable. Our general predictions are summarized in Table 2.

All models were performed using restricted maximum likelihood and including the sampling variance of effect sizes. We interpreted the models estimates based on their $95 \%$ confident interval $(\mathrm{CI})$ and the inclusion of zero in this interval. If CI does not include zero, we considered the estimated effect size as significant.

Table 2. General predictions about the net outcome of plant interactions in coastal dunes, considering different combination of life forms and ontogenetic stages of neighbor and target plants.

\begin{tabular}{cccc}
\hline Neighbor & Target & Target & Hedges' d \\
life form & life form & ontogenetic stage & \\
\hline herb & herb & not seedling & 0 or - \\
herb & herb & seedling & - \\
herb & woody & not seedling & 0 \\
herb & woody & seedling & - \\
woody & herb & not seedling & - \\
woody & herb & seedling & - \\
woody & woody & not seedling & 0 or - \\
woody & woody & seedling & + \\
\hline
\end{tabular}




\section{Heterogeneity}

Because heterogeneity among data is expected in biological meta-analyses, we calculated for every model the total statistic heterogeneity $\left(\mathrm{I}^{2}\right)$ and the statistic heterogeneity associated to each random factor. $\mathrm{I}^{2}$ varies from 0 to $100 \%$ and represents how much of the variation between effect sizes is due to variance between studies and, therefore, is a way to measure the variation that is not explained by sampling variance (Nakagawa \& Santos 2012). We first assessed the total heterogeneity for models without fixed predictors and, then, calculated the heterogeneity for models with fixed predictor in order to investigate if the environmental condition and the features of interacting plants can account for part of the variation among data.

\section{Publication bias and sensitivity analyses}

We tested for publication bias using Egger's regression test (Egger et al. 1997, Stern \& Egger 2005) and Orwin's fail safe number. When the intercept of the Egger's regression is different from zero, the relationship between model residuals and original variances of effect sizes is considered asymmetrical and represents a bias (Stern \& Egger 2005). We considered the estimate of intercept different from zero at p-value lower than 0.05. We also calculated the Orwin's number, which represents the number of studies averaging null results (fail safe number) that would have to be added to the set of observed outcomes to reduce the unweighted average effect size to a target value (Orwin 1983). We chose an effect size equal to 0.05 as target average effect size, considering that this value is small enough to represent absence of ecological meaning.

To follow recent recommendations about how outliers and influential data points may affect the magnitude of estimated effects (Viechtbauer \& Cheung 2010, Nakagawa et al. 2017), we proceeded a sensitivity test for identify these points. We defined outliers as outcomes with 
standardized residual values exceeding 2.0 and influential values as outcomes sizes with hat values greater than two times the average hat value (Viechtbauer \& Cheung 2010, Aguinis et al. 2013). If an outcome was simultaneously outlier and influential, we excluded it from analyses and evaluated sensitivity by comparing results from models with and without these influential outliers.

Although each performance variable had at least five outcomes, some combinations of life forms and ontogenetic stages of neighbors and targets could result in sample sizes smaller than five for that combination. When a combination had less than three outcomes, we repeated the analyses excluding it. For survival, most of combinations including herbaceous neighbor had two or less outcomes and, therefore, we analyzed only combinations with woody neighbors. For growth, most of combinations with seedling targets had only one outcome, so we analyzed only the data from not seedling targets, including neighbors and targets life forms as fixed predictors. For reproduction, the combination of herbaceous neighbor and woody target had only one outcome, and it was also excluded from analysis.

All analyses were conducted with packages metafor (Viechtbauer 2010), raster (Hijmans 2017) and ggplot2 (Wickham 2016) in R environment (R Development Core Team 2018).

\section{RESULTS}

\section{General characterization of data set}

We found 406 papers in our search and included 28 in this meta-analysis, which provided a total of 235 outcomes. Published between 1991 and 2016, these studies were conducted in 10 countries, but almost one third of the outcomes $(32.8 \%)$ are from coastal dunes in the United States of America (USA). Therefore, there is a strong bias for temperate regions $(90.2 \%)$, while tropical (5.07\%), subtropical (3.38\%) and artic zones (1.35\%) are far less 
represented. In terms of sampling design, most outcomes derived from an observational approach $(58.11 \%)$, compared to an experimental one.

\section{Factors affecting plant interactions}

The harshness of environmental conditions, expressed as a global aridity index, affects the net outcome of interactions in coastal dunes only when reproduction is considered as performance variable (Fig. 2). Plants features, on the other side, are important factors determining the net outcome of interactions for survival, reproduction and growth (Fig. 3). As expected, woody seedlings present a higher survival rate when growing under the canopy of woody neighbors than when growing in open areas (Fig. 3B). On the other hand, survival of woody seedlings seems to be negatively affected by herbaceous neighbors, although this result must be considered with caution since it is based in only one effect size and, therefore, lacks reliability (Fig. 3B). When considering herbaceous targets, growth and reproduction of adult individuals are enhanced in the presence of herbaceous and woody neighbors, respectively (Fig. $3 \mathrm{C}$ and $3 \mathrm{D}$ ), a result contrary to our expectation. For abundance, the presence of neighbors does not affect the performance of targets (Fig. 3A).

\section{Heterogeneity}

The heterogeneity among data is high, above $60 \%$ in all cases (Table S3). The inclusion of GAI values as predictors did not reduce heterogeneity for any data set. The inclusion of plant life form and ontogenetic stage reduced heterogeneity for survival and reproduction models. For these two performance variables, the random factors that accounted for most heterogeneity were the identity of neighbor species and the identity of study, respectively. For abundance and growth, the identity of target species was the most explanatory random factor. Nevertheless, a high degree of heterogeneity remained after the inclusion of predictors, indicating that variables 
other than ones included in this analysis may be important to determine the net outcome of plant interactions.

\section{Publication bias and sensitivity}

We detected publication bias for abundance and reproduction data used in the models of environmental conditions (Table S4), indicating that studies with small sample size are only published if they show large effect sizes. On the other hand, Orwin's fail safe number for these data sets were high ( $\geq 179$ studies; Table S4), which indicates that, despite of publication bias, the results are robust. We also detected an influential outlier in the data set evaluating the effect of environmental conditions for abundance (Fig. S1). The exclusion of this influential outlier did not alter the results qualitatively (linear regression: $-0.81+0.76 x[-0.40,1.92])$. Considering models for plant features, we did not detect any influential outliers (Fig. S2). The exclusion of plant features combinations with small number of outcomes also did not affect the results in a qualitative manner (Fig. S3). 


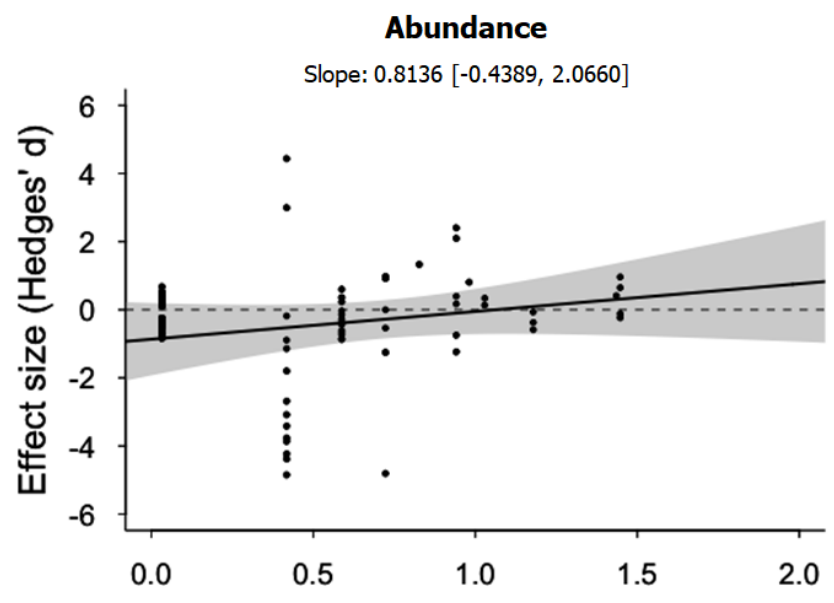

A

Survival

B
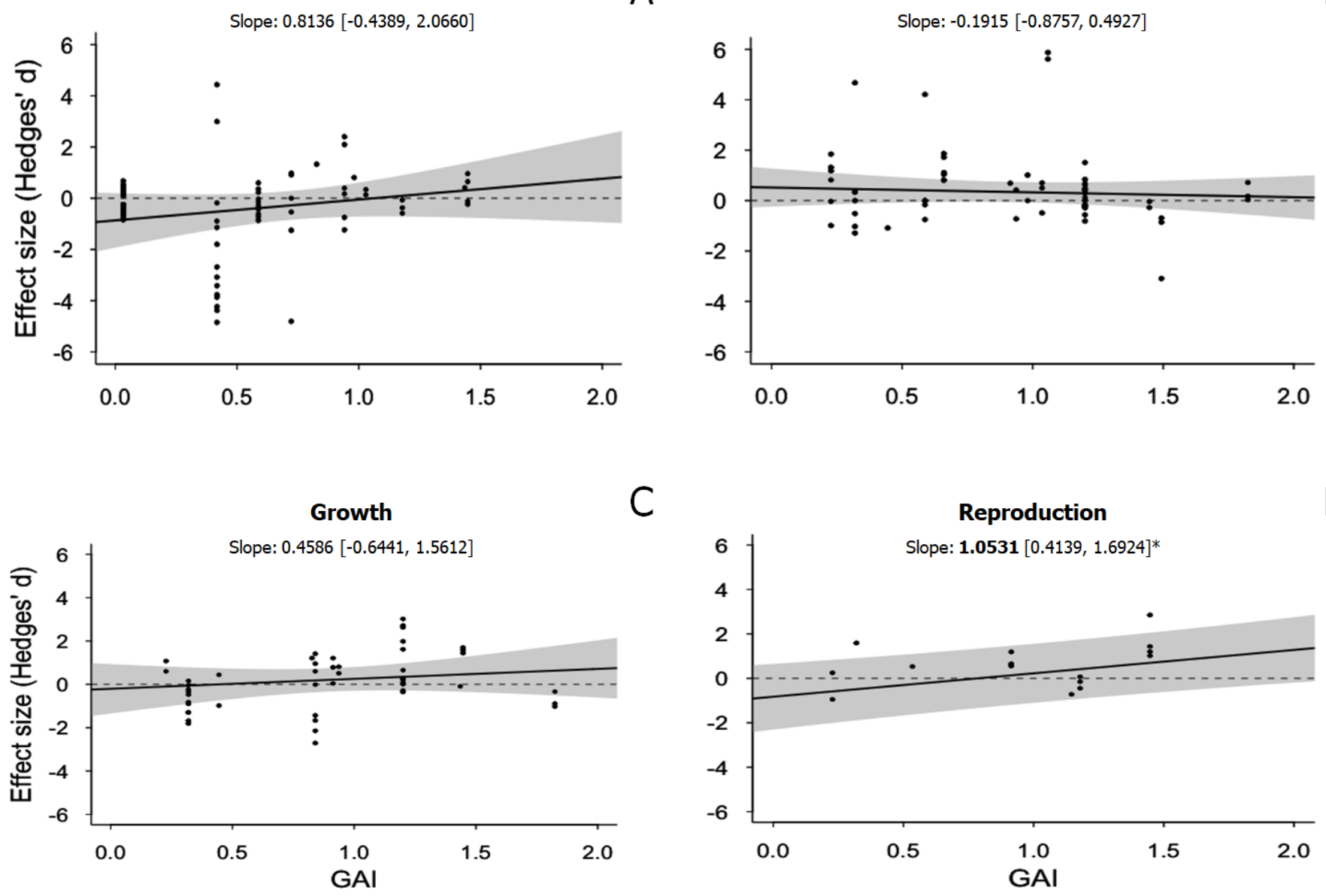

C

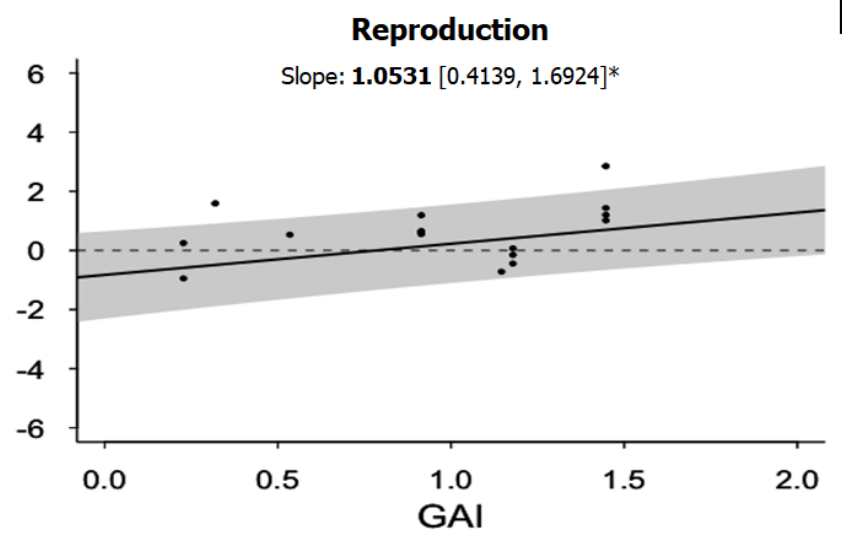

Figure 2. Effect of environmental conditions on net outcome of interactions in sandy coastal dunes, for each performance variable. Environmental conditions are expressed as global aridity index (GAI), with higher values of GAI indicating moister enviroments. Net outcome of interaction is presented as Hedges'd, with positive values indicating facilitation and negative values indicating competition. Points represent effect sizes calculated from original data. Thick black line represents the predicted adjustment of the hierarchical model with GAI as predictor. Gray area represents $95 \%$ confidence interval. Asterisks denote a slope significantly different from zero. 


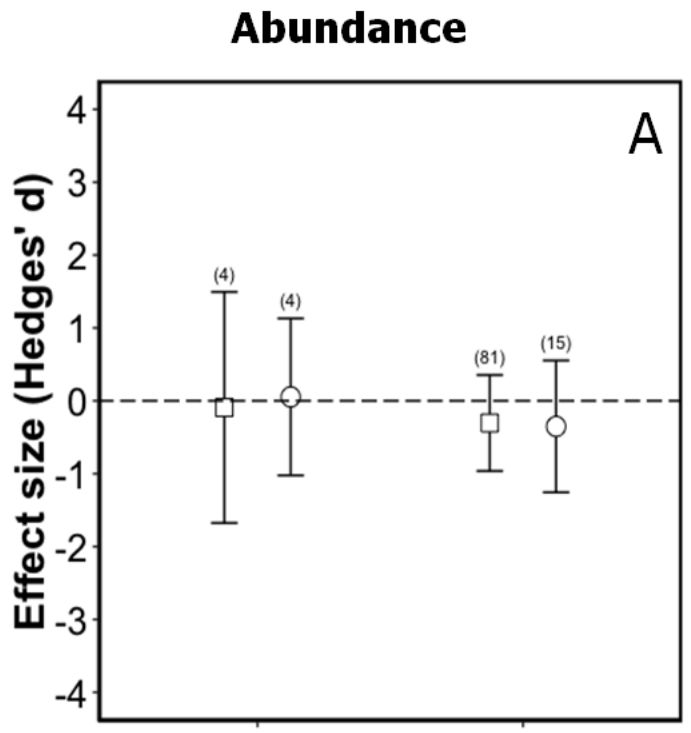

Growth

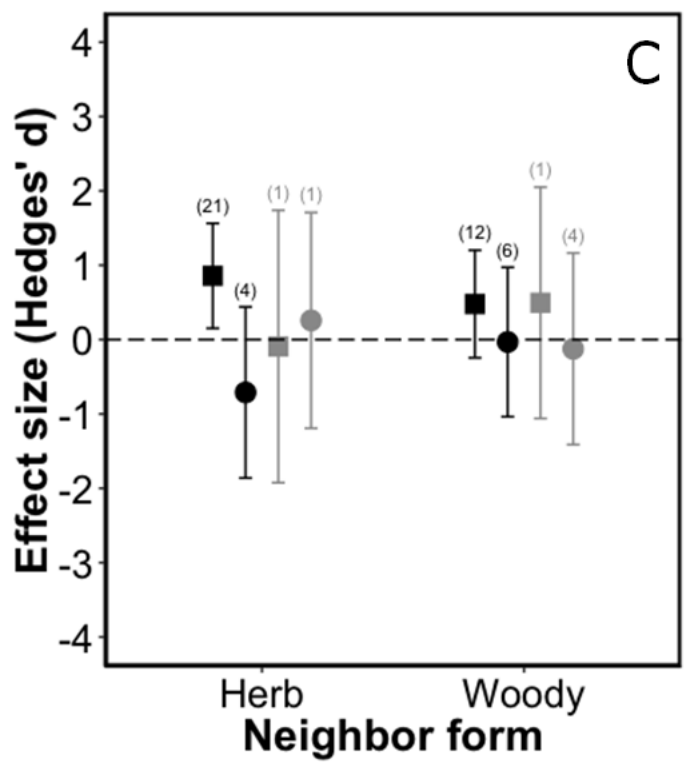

Survival

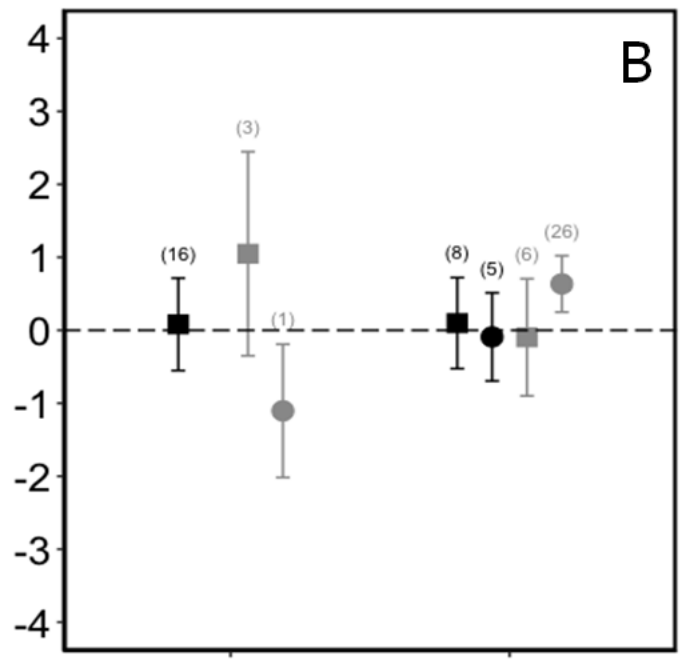

Reproduction

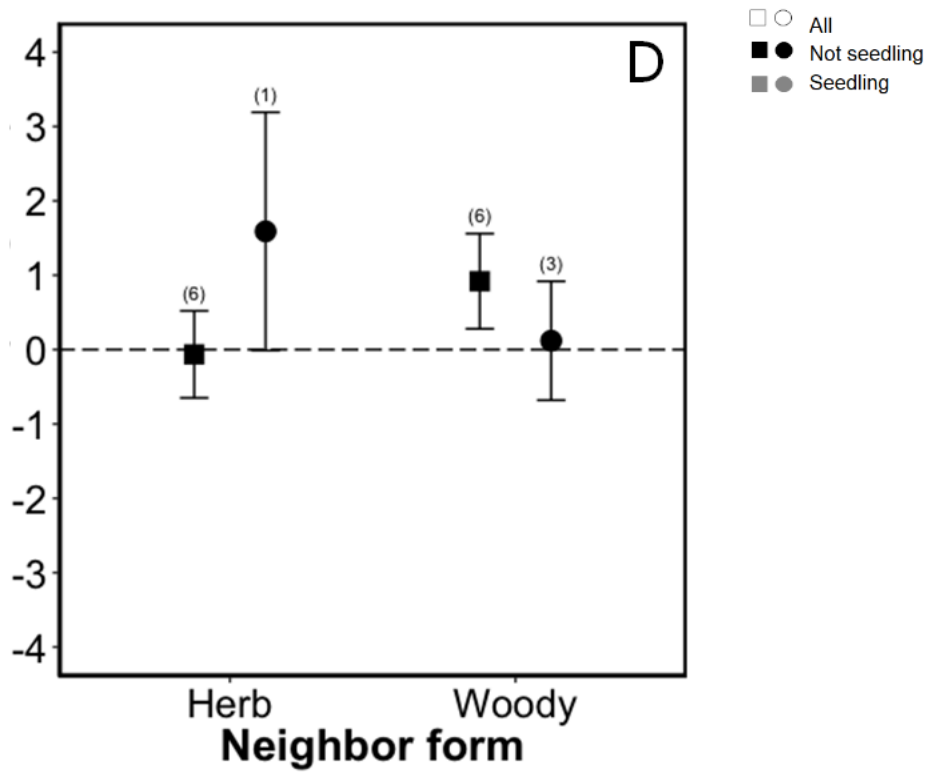

Figure 3. Predicted net outcome of interactions for combinations of plant life form and ontogenetic stage in sandy coastal dunes, for each performance variable. Net outcome of interaction is presented as Hedges'd, with positive values indicating facilitation and negative values indicating competition. Vertical bars represent $95 \%$ confidence interval. Numbers above bars represent the number of outcomes in the respective combination. For survival, the combination of herbaceous neighbors and not seedling woody targets had no outcome. 


\section{DISCUSSION}

Variation in the net outcome of plant-plant interaction has been largely debated, with several proposals of factors that may influence this outcome, such as environmental conditions and characteristics of interacting individuals. In this meta-analysis, we found evidence of roles of environmental conditions, plant life form and plant ontogenetic stage in determining the outcome of plant interactions in coastal dunes. However, the influence of these factors depends largely on what performance variable is considered and on specific combinations of life form and ontogenetic stages of interacting individuals. These results highlight the contextdependence of plant interactions in coastal dunes around the world and the importance of quantitative synthesis to reveal contingencies and gaps in ecological knowledge.

\section{Effects of environmental conditions}

We found evidence that environmental conditions are relevant only when we consider reproduction as performance measure. In these cases, competition tends to predominate in harsher conditions, contradicting the traditional stress-gradient hypothesis (SGH) (Bertness \& Callaway 1994). In more severe environments, neighbor plants have been recognized as capable of ameliorate microclimatic conditions and have positive effects on plants in their understories (He et al. 2013), but they can also reduce light availability, compete for nutrients and soil moisture or reduce the amount of water reaching the soil through canopy interception (van der Waal et al. 2009, Esquivias et al. 2015, Metz \& Tielbörger 2016). These effects may work on the opposite direction of facilitation, resulting in neutral and even negative outcomes of interactions.

In fact, there is evidence that the soil water content and hydraulic conductivity is lower within vegetation patches than in the open areas in Mediterranean coastal dunes (Esquivia et al. 2014, Bar-Kutiel et al. 2016, but see Liancourt et al. 2005 in mesoxeric grassland). Besides 
competition for limiting resources, the reduced water availability in vegetation patches may be due to soil water repellency by accumulation of hydrophobic compounds, especially in superficial soil layers, through decomposition of plant litter (Siteur et al. 2016). In coastal dunes, the negative effects of water soil repellency tend to be greater in drier environments and for herbaceous plants, since they are less capable of finding water in deep soil layers than woody species (Siteur et al. 2016). Considering that herbs are the most common targets in our data set for reproduction ( $75 \%$ of the outcomes), they might be driving the pattern of increase in negative effects towards harsher environmental conditions. Another factor that must be considered is that a collapse of facilitation under severe environmental conditions may be due to reductions in the positive effects of the neighbor plant. In extreme environments, grazing and resource stresses may decrease plant size and, consequently, the neighbor ability to ameliorate microclimate and resource availability under its canopy (Michalet et al. 2014).

The absence of impacts of environmental conditions on growth might be related to differences in intrinsic growth rate of target species among studies. If studies that were conducted in more humid coastal dunes evaluated growth for species with low growth rates, the benefits provided by the neighbors would not be detectable in short to medium times, which is the duration of most field researches. This seems to be the case for the outcomes with GAI higher than 1.5 in our growth data set, derived from the slow growing tree Ternstroemia brasiliensis as target (Castanho \& Prado 2014). We suggest that further studies investigate the mechanisms, conditions and resources underlying plant interactions for different performance variables, especially growth, as well the interaction between environmental conditions, plant life forms and plant growth rates.

For survival, which has direct positive effects on abundance, the outcome of plant interactions might be neutral due to the interplay between microclimatic conditions, resource availability and competitive ability. In drier environments, positive effects of microclimatic 
amelioration (Castanho \& Prado 2014) may be conteracted by negative effects of reduced water availability (Maestre \& Cortina 2004), leading to neutral outcomes of plant interactions. When environmental severity is low, positive effects of higher abundance of soil resources and naturally milder microclimatic conditions might also be counterbalanced by increases in the competitivity between plants, due to the higher proportion of species with ecological strategy that maximizes resource acquisition (Grime 2001, Reich et al. 2003, Wright et al. 2004). As consequence, the outcome of interactions would still be neutral for abundance and survival when the environmental conditions become milder.

\section{Effects of plants features}

We found that effects of life form and ontogenetic stages on outcome of plant interactions are important for survival, growth and reproduction, but does not affect abundance of target plants. For survival we found a higher survival rate of woody seedlings when growing under the canopy of a woody neighbor. This may be related to microclimatic amelioration under the canopy of woody neighbors (Kitzberger et al. 2000), without the negative effects associated to the overlap of radicular systems, since woody adults have deeper roots than seedlings, resulting in vertical segregation of water and nutrient uptake.

The neutral effects of woody neighbors on survival of herbaceous seedlings is probably due to an interplay between changes in environment by neighbors and tolerance of target species to stressful conditions. In fact, an initial alleviation of environmental stress, especially thermal and water stress may lead to positive outcomes of interaction among plants (Martinez et al. 2003, Liancourt et al. 2005, Bagousse-Pinguet et al. 2013). Reduction in light availability under the canopy of a neighbor, however, might decrease photosynthetic performance of herbs to a level that counterbalances the positive effects of improvement in thermal and water conditions (Forseth et al. 2001, Sage 2017). As consequence, the net outcome of interaction becomes 
neutral. Effects of neighbors on herbaceous plants might also depend on adaptations of target species to the harsh conditions of coastal dunes, with stress-intolerant species presenting a positive response to neighbors and stress-tolerant species a negative response (Liancourt et al. 2005).

Both woody and herbaceous neighbors had neutral effects on the survival of adult targets. This is probably because once a plant is established and overcome the initial and most vulnerable ontogenetic stages, especially for woody species (Fenner 1987, Leck et al. 2008), the probability of mortality by interaction with a neighbor substantially drops. However, neighbor plants would affect other performance responses of adult targets, such as growth and reproduction.

Absence of impacts of neighbor plants on the abundance of targets may be related to the overall neutral effects on survival, since a higher survivorship is expected to be directly related to a higher abundance of plants. Although we have found that woody neighbors enhance the survival of seedling woody targets, we were not able to incorporate target ontogenetic stage in the analysis of abundance. Therefore, this effect might be masked by the mixture of different ontogenetic-stages.

Surprisingly, woody neighbors also facilitate the reproduction of herbaceous plants. Neighbor plants with attractive flowers could enhance the pollinator service of plants under their canopies by acting as "magnet species" for pollinators or by positive density-dependence effects (Ghazoul 2006, Molina-Montenegro et al. 2008, but see McKinney \& Goodell 2010). Furthermore, in our data set, positive outcomes of plant interactions may also be due to increase in resources availability by woody plants, especially nutrients. In fact, in $66 \%$ of the outcomes used in this analysis, the neighbor species was Myrica pensylvanica, a nitrogen-fixing shrub (Shumway 2000). Nitrogen-fixing plants enhance the amount of nutrient being cycled and the accumulation of nitrogen and organic carbon, resulting in islands of fertility under their 
canopies (Kleinhesselink et al. 2014, Stinca et al. 2015). As consequence, the increase in nutrient availability allows surrounding species to have higher investiment in reproduction (Kleinhesselink et al. 2014, Stinca 2015, but see Macek et al. 2016). Besides reproduction, increases in resource availability may have positive impacts on plant growth. Nevertheless, we did not detect any effect of woody neighbors on growth of target plants, perhaps because in these outcomes neighbors are mostly non-nitrogen-fixing (76\% of outcomes). In these cases, neighbors might be able to improve environmental conditions to a level enough to neutralize the negative effects of competition and light limitation but not enough to result in a positive outcome of interaction.

Contrary to the expected, herbaceous neighbors facilitate the growth of adult herbaceous plants. It is probably due to improved soil resources conditions in clumps of herbaceous neighbors. In the shelter of clumps or surrounded vegetation, such as cushions in other environments (Schöb et al. 2012), soil water and soil organic matter content are higher than in open areas, leading to more favorable growth conditions. Growing in clumps with other herbs may also make the target species less apparent or accessible to herbivores, reducing biomass losses and being especially advantageous when the neighbor incurs minimal costs for the target (Cushman et al. 2011), for instance, when target has high competitive ability. However, when target species are competitively inferior to their neighbors, the negative effects of interspecific competition may predominate in the interaction, as suggested by Cheplick (2005). Plant competitive ability then might also help explain the neutral effects of herbaceous neighbors on reproduction of herbs, if the competitive ability of target species compared to their neighbors varies greatly among studies in the reproduction data set.

The small number of empirical tests about the effects of herbaceous species on woody targets did not allow us to obtain reliable estimates of the general outcome of interactions for this combination. The same limitation applies to the effects of herbaceous neighbors on 
seedlings of both life forms. It is important to increase the number of studies that investigate plant interactions considering these combinations of plant life forms and ontogenetic stages in the future.

\section{Recommendations and implications}

Our results highlight some gaps in the literature of plant-plant interactions in coastal dunes. Although the combination of life form and ontogenetic stage is relevant to determine the outcome of plant interactions, other plant features, such as competitive ability of neighbors and targets, should also be investigated (Michalet et al. 2006, Maestre et al. 2009). Differences in results among performance variables may be related to specific mechanisms determining the relative importance of resource uptake and resource use to the performance of interest. Therefore, the effects of traits related to water use efficiency and nitrogen use efficiency, such as stomatal regulation and enzymatic contents (Harris et al. 2017), on the outcome of interactions should be investigated in coastal dunes. Traits related to resource uptake or interception, such as root profile and plant height, should also be taken in account (Armas \& Pugnaire 2009, Navas \& Violle 2009). Furthermore, it is important to assess the generality of positive effects of nitrogen-fixing neighbors in different ecological contexts.

The influence of indirect interactions (e.g. herbivory and pollination) on how a neighbor plant affects the performance of a target is another factor that should be taken in account in further studies. A formal synthesis of facilitation complexes involving shrubs, their associated plant species and animals has been proposed (Lortie et al. 2016), but the conceptual framework needs to be extended to other plant life forms. Finally, we recommend that plant life forms, ontogenetic stages and environmental conditions should be considered simultaneously in order to enhance our understanding about how the outcome of interactions changes among plants in different environments. Unfortunately, we were not able to analyze all these factors 
simultaneously due to lack of sample size of different combinations of plant life form, plant ontogenetic stage and environmental conditions. Increase in primary studies investigating these factors simultaneously is important and may allow a broader review or meta-analysis in the near future.

Our study also contributes to the understanding of the development and maintenance of plant communities is coastal dunes. The observed facilitation of woody seedlings by woody neighbors has the potential to establish a positive feedback favoring the occupation of the environment by woody species along the time. This positive feedback may explain the changes in plant community diversity and composition along coastal dune gradients, in which herbaceous plants predominate in primary dunes and woody species increasingly dominate the community towards inland dunes (Miller et al. 2010). The increase of woody plant diversity by nurse plants in arid scrubland and mesic forests has been proposed as one of the drivers of state transitions in vegetation (Rey et al. 2016). The role of facilitation in critical transitions is considered especially important to protect plant communities in harsh environments in face of climate change and intensified land use (Cavieres et al. 2014, Verwijmeren et al. 2013).

Furthermore, our findings have practical implications for restoration of sandy coastal plains. During the last years, several studies have highlighted the importance of facilitation and nucleation effects in restoration projects (Padilla \& Pugnaire 2006, Gómez-Aparicio 2009, Zahawi et al. 2013, Bertoncello et al. 2016, Teixeira et al. 2016). Nevertheless, the selection of potential nurse species and environmental conditions more favorable to restoration success remains challenging. We found evidence that, in areas of scrubland or beach forests, woody species can reduce the mortality of woody seedlings and minimize one of the great problems in restoration projects (Leck et al. 2008). Therefore, planting species in small patches may be more efficient and less dispendious than the traditional strategy of planting isolated seedlings in rows (Corbin \& Holl 2012). In primary dunes, where the predominant vegetation is 
herbaceous, planting species in aggregation could also be applied to enhance growth of individuals.

According to our results, the success of using neighbors to improve performance of targets in restorations tend to be higher in coastal dunes under less arid conditions, at least for reproduction. In a meta-analysis with studies that have manipulated plant interaction in the context of restoration of degraded systems, Gómez-Aparicio (2009) also found that positive effects of neighbors on plant performance was not restricted to stressful systems and depended largely on the life-history of interaction species. All these results combined suggest that the choice of potential nurses depends on characteristics of target plants, as well on the performance estimator that is intended to enhance. Nevertheless, facilitation has the potential to be successfully applied in conservation and restoration of coastal dunes and efforts to identify and preserve nurse plants in these environments should be estimulated (Scarano 2002).

\section{CONCLUSions}

- Environmental conditions influence the effect of neighbors on the reproduction of target plants, with competition prevailing in more arid coastal dunes. Contrary to the stress-gradient hypothesis, this pattern suggests that reduction in resource availability through resource competition and interference overcomes the positive effects of microclimatic amelioration by neighbors in more severe environments. The interplay between environmental conditions and characteristics of plants, such as life-forms, growth rate and competitive ability, might explain the absence of effects for other performance variables and should be investigated in future studies.

- The interaction between plant life form and ontogenetic stage is relevant for the outcome of plant interactions. Woody neighbors facilitate the survival of woody seedlings, but do not affect the survival of herbaceous seedlings, probably due to 
differences in tolerance of target species to stressful conditions and shade provided by the canopy of neighbors. For adult targets, the presence of neighbors influences only growth and reproduction. Woody neighbors facilitate reproduction of herbs, probably due to improvement in resource conditions, such as increase in nutrient availability by nitrogen-fixing neighbors. On the other hand, herbaceous neighbors facilitate the growth of other herbs, which might be related to enhance in soil resources conditions inside clumps and protection against herbivory. The benefits of neighbors might be influenced by competitive ability of both targets and neighbor plants.

- Positive interactions found in our study support the ideias that facilitation is a key factor determining positive feedbacks in successional gradients and leading critical transitions in coastal dunes. Furthermore, they should be considered as a valuable tool in restoration of these ecosystems.

- We provide evidence for context-dependence of the outcome of plant interactions in coastal dunes and highlight important gaps in ecological knowledge. Further studies should investigate how herbaceous neighbors affect woody targets and seedlings, as well the influence of traits related to resource use and uptake and of indirect facilitation on the outcome of interactions. We also recommend that the interplay between environmental conditions, plant life forms and plant ontogenetic stages should be considered simultaneously. 


\section{REFERENCES}

Aguinis, H., Gottfredson, R.K. \& Joo, H. 2013. Best-practice recommendations for defining, identifying, and handling outliers. Organizational Research Methods 16:270-301.

Aranda, I., Pardos, M., Puertolas, J., Jimenez, M.D. \& Pardos, J.A. 2007. Water-use efficiency in cork oak (Quercus suber) is modified by the interaction of water and light availabilities. Tree Physiology 27: 671-677.

Armas, C. \& Pugnaire, F.I. 2009. Ontogenetic shifts in interactions of two dominant shrub species in a semi-arid coastal sand dune system. Journal of Vegetation Science 20: 535546.

Bagousse-Pinguet, Y., Forey, E., Touzard, B. \& Michalet, R. 2013. Disentangling the effects of water and nutrients for studying the outcome of plant interactions in sand dune ecosystems. Journal of Vegetation Science 24: 375-383.

Bar-Kutiel, P., Katz, O., Ziso-Cohen, V., Divinsky, I. \& Katra, I. 2016. Water availability in sand dunes and its implications for the distribution of Artemisia monosperma. CATENA 137: $144-151$.

Bateman, A., Lewandrowski, W., Stevens, J.C. \& Miriam, M.-R. 2018. Ecophysiological indicators to assess brought responses of arid zone native seedlings in reconstructed soils. Land Degradation \& Development 29: 984-993.

Berger, U., Piou, C., Schiffers, K. \& Grimm, V. 2008. Competition among plants: Concepts, individual-based modelling approaches, and a proposal for a future research strategy. Perspectives in Plant Ecology, Evolution and Systematics 9: 121-135.

Bertness, M.D. \& Callaway, R. 1994. Positive interactions in communities. Trends in Ecology \& Evolution 9: 191-193.

Bertoncello, R., Oliveira, A.A., Holl, K.D., Pansonato, M.P. \& Martini, A.M.Z. 2016. Cluster planting facilitates survival but not growth in early development of restored tropical forest. Basic and Applied Ecology 17: 489-496.

Bitton, M.C.A. \& Hesp, P.A. 2013. Vegetation dynamics on eroding to accreting beachforedune systems, Florida panhandle. Earth Surface Processes and Landforms 38: 14721480 .

Bonanomi, G., Incerti, G. \& Mazzoleni, S. 2011. Assessing occurrence, specificity, and mechanisms of plant facilitation in terrestrial ecosystems. Plant Ecology 212: 1777.

Borenstein, M., Hedges, L.V., Higgins, J.P.T. \& Rothstein, H.R. 2009. Introduction to MetaAnalysis, Wiley, New Jersey. 
Brooker, R.W., Maestre, F.T., Callaway, R.M., Lortie, C.L., Cavieres, L.A., Kunstler, G., Liancourt, P., Tielbörger, K., Travis, J.M.J., Anthelme, F., Armas, C., Coll, L., Corcket, E., Delzon, S., Forey, E., Kikvidze, Z., Olofsson, J., Pugnaire, F., Quiroz, C.L., Saccone, P., Schiffers, K., Seifan, M., Touzard, B. \& Michalet, R. 2008. Facilitation in plant communities: the past, the present, and the future. Journal of Ecology 96: 18-34.

Brooker, R.W. \& Callaghan, T.V. 1998. The balance between positive and negative plant Interactions and its relationship to environmental gradients: a model. Oikos 81: 196-207. Callaway, R.M., Brooker, R.W., Choler, P., Kikvidze, Z., Lortie, C.J., Michalet, R., Paolini, L., Pugnaire, F.I., Newingham, B., Aschehoug, E.T., Armas, C., Kikodze, D. \& Cook, B.J. 2002. Positive interactions among alpine plants increase with stress. Nature 417: 844.

Castanho, C.d.T., Lortie, C.J., Zaitchik, B. \& Prado, P.I. 2015a. A meta-analysis of plant facilitation in coastal dune systems: responses, regions, and research gaps. PeerJ 3: e768.

Castanho, C.T., Oliveira, A.A. \& Prado, P.I.K.L. 2015b. Does extreme environmental severity promote plant facilitation? An experimental field test in a subtropical coastal dune. Oecologia 178: 855-866.

Castanho, C.T. \& Prado, P.I. 2014. Benefit of shading by nurse plant does not change along a stress gradient in a coastal dune. PLOS ONE 9: e105082.

Castanho, C.T., Oliveira, A.A. \& Prado, P.I. 2012. The importance of plant life form on spatial associations along a subtropical coastal dune gradient. Journal of Vegetation Science 23: 952-961.

Cavieres, L.A., Brooker, R.W., Butterfield, B.J., Cook, B.J., Kikvidze, Z., Lortie, C.J., Michalet, R., Pugnaire, F.I., Schöb, C., Xiao, S., Anthelme, F., Björk, R.G., Dickinson, K.J.M., Cranston, B.H., Gavilán, R., Gutiérrez-Girón, A., Kanka, R., Maalouf, J.-P., Mark, A.F., Noroozi, J., Parajuli, R., Phoenix, G.K., Reid, A.M., Ridenour, W.M., Rixen, C., Wipf, S., Zhao, L., Escudero, A., Zaitchik, B.F., Lingua, E., Aschehoug, E.T. \& Callaway, R.M. 2014. Facilitative plant interactions and climate simultaneously drive alpine plant diversity. Ecology Letters 17: 193-202.

Cheplick, G.P. 2005. Patterns in the distribution of American beachgrass (Ammophila breviligulata) and the density and reproduction of annual plants on a coastal beach. Plant Ecology 180: 57-67.

Cipriotti, P.A., Aguiar, M.R., Wiegand, T. \& Paruelo, J.M. 2014. A complex network of interactions controls coexistence and relative abundances in Patagonian grass-shrub steppes. Journal of Ecology 102: 776-788. 
Corbin, J.D. \& Holl, K.D. 2012. Applied nucleation as a forest restoration strategy. Forest Ecology and Management 265: 37-46.

Craine, J.M. \& Dybzinski, R. 2013. Mechanisms of plant competition for nutrients, water and light. Functional Ecology 27: 833-840.

Cushman, J.H., Lortie, C.J. \& Christian, C.E. 2011. Native herbivores and plant facilitation mediate the performance and distribution of an invasive exotic grass. Journal of Ecology 99: 524-531.

Cusseddu, V., Ceccherelli, G. \& Bertness, M. 2016. Hierarchical organization of a Sardinian sand dune plant community. PeerJ 4: e2199.

Dohn, J., Dembélé, F., Karembé, M., Moustakas, A., Amévor Kosiwa, A. \& Hanan Niall, P. 2013. Tree effects on grass growth in savannas: competition, facilitation and the stressgradient hypothesis. Journal of Ecology 101: 202-209.

Egger, M., Davey-Smith, G., Schneider, M. \& Minder, C. 1997. Bias in meta-analysis detected by a simple, graphical test. BMJ : British Medical Journal 315: 629-634.

Escós, J., Alados, C.L., Pugnaire, F.I., Puigdefábregas, J. \& Emlen, J. 2000. Stress resistance strategy in an arid land shrub: interactions between developmental instability and fractal dimension. Journal of Arid Environments 45: 325-336.

Esquivias, M.P., Zunzunegui, M., Díaz Barradas, M.C. \& Álvarez-Cansino, L. 2015. Competitive effect of a native-invasive species on a threatened shrub in a Mediterranean dune system. Oecologia 177: 133-146.

Esquivias, M.P., Zunzunegui, M., Barradas, M.C.D. \& Álvarez-Cansino, L. 2014. The role of water use and uptake on two Mediterranean shrubs' interaction in a brackish coastal dune ecosystem. Ecohydrology 7: 783-793.

February, E.C., Higgins, S.I., Bond, W.J. \& Swemmer, L. 2013. Influence of competition and rainfall manipulation on the growth responses of savanna trees and grasses. Ecology 94: $1155-1164$.

Fenner, M. 1987. Seedlings. New Phytologist 106: 35-47.

Fenu, G., Carboni, M., Acosta, A.T.R. \& Bacchetta, G. 2013. Environmental factors influencing coastal vegetation pattern: new insights from the mediterranean basin. Folia Geobotanica 48: 493-508.

Forey, E., Lortie, C.J. \& Michalet, R. 2009. Spatial patterns of association at local and regional scales in coastal sand dune communities. Journal of Vegetation Science 20: 916-925. 
Forseth, I.N., Wait, D.A. \& Casper, B.B. 2001. Shading by shrubs in a desert system reduces the physiological and demographic performance of an associated herbaceous perennial. Journal of Ecology 89: 670-680.

Foster, B.L. 2002. Competition, facilitation, and the distribution of Schizachyrium scoparium along a topographic-productivity gradient. Écoscience 9: 355-363.

Franks, S.J. 2003. Competitive and facilitative interactions within and between two species of coastal dune perennials. Canadian Journal of Botany 81: 330-337.

Ghazoul, J. 2006. Floral diversity and the facilitation of pollination. Journal of Ecology 94: 295-304.

Gómez-Aparicio, L. 2009. The role of plant interactions in the restoration of degraded ecosystems: a meta-analysis across life-forms and ecosystems. Journal of Ecology 97: 1202-1214.

Gómez-Aparicio, L., Zamora, R., Gómez, J.M., Hódar, J.A., Castro, J. \& Baraza, E. 2004. Applying plant facilitation to forest restoration: a meta-analysis of the use of shrubs as nurse plants. Ecological Applications 14: 1128-1138.

Grime, J.P. 2001. Plant strategies, vegetation processes, and ecosystem properties, Wiley, New Jersey.

Guido, A., Salengue, E. \& Dresseno, A. 2017. Effect of shrub encroachment on vegetation communities in Brazilian forest-grassland mosaics. Perspectives in Ecology and Conservation 15: 52-55.

Harris, A.L., Zinnert, J.C. \& Young, D.R. 2017. Differential response of barrier island dune grasses to species interactions and burial. Plant Ecology 218: 609-619.

Hastwell, G.T. \& Facelli, J.M. 2003. Differing effects of shade-induced facilitation on growth and survival during the establishment of a chenopod shrub. Journal of Ecology 91: 941950.

He, Q., Bertness, M.D. \& Altieri, A.H. 2013. Global shifts towards positive species interactions with increasing environmental stress. Ecology Letters 16: 695-706.

Hijmans, R.J. 2017. Raster: Geographic Data Analysis and Modeling (R package version 2.67), Retrieved from https://CRAN.R-project.org/package=raster.

Holmgren, M., Gómez-Aparicio, L., Quero, J.L. \& Valladares, F. 2012. Non-linear effects of drought under shade: reconciling physiological and ecological models in plant communities. Oecologia 169: 293-305. 
Holmgren, M. \& Scheffer, M. 2010. Strong facilitation in mild environments: the stress gradient hypothesis revisited. Journal of Ecology 98: 1269-1275.

Holzapfel, C., Tielbörger, K., Parag, H.A., Kigel, J. \& Sternberg, M. 2006. Annual plant-shrub interactions along an aridity gradient. Basic and Applied Ecology 7: 268-279.

Holzapfel, C. \& Mahall, B.E. 1999. Bidirectional facilitation and interference between shrubs and annuals in the mojave desert. Ecology 80: 1747-1761.

Joy, D.A. \& Young, D.R. 2002. Promotion of mid-successional seedling recruitment and establishment by Juniperus virginiana in a coastal environment. Plant Ecology 160: 125135.

Kew Royal Botanic Gardens. 2017. Plants of the world online. URL: http://powo.science.kew.org/.

Kitzberger, T., Steinaker, D.F. \& Veblen, T.T. 2000. Effects of climatic variability on facilitation of tree establishment in northern Patagonia. Ecology 81: 1914-1924.

Kleinhesselink, A.R., Magnoli, S.M. \& Cushman, J.H. 2014. Shrubs as ecosystem engineers across an environmental gradient: effects on species richness and exotic plant invasion. Oecologia 175: 1277-1290.

Koricheva, J., Gurevitch, J. \& Mengersen, K. 2013. Handbook of meta-analysis in ecology and evolution, Princeton University Press.

Lane, C., Wright, S.J., Roncal, J. \& Maschinski, J. 2008. Characterizing environmental gradients and their influence on vegetation zonation in a subtropical coastal sand dune system. Journal of Coastal Research 24: 213-224.

Leck, M.A., Parker, V.T. \& Simpson, R.L. 2008. Seedling Ecology and Evolution, Cambridge University Press, Cambridge.

Liancourt, P., Callaway, R.M. \& Michalet, R. 2005. Stress tolerance and competitive-response ability determine the outcome of biotic interactions. Ecology 86: 1611-1618.

Lichter, J. 2000. Colonization constraints during primary succession on coastal Lake Michigan sand dunes. Journal of Ecology 88: 825-839.

Lortie, C.J., Filazzola, A. \& Sotomayor, D.A. 2016. Functional assessment of animal interactions with shrub-facilitation complexes: a formal synthesis and conceptual framework. Functional Ecology 30: 41-51.

Lortie, C.J., Brooker, R.W., Choler, P., Kikvidze, Z., Michalet, R., Pugnaire, F.I. \& Callaway, R.M. 2004. Rethinking plant community theory. Oikos 107: 433-438. 
Macek, P., Prieto, I., Macková, J., Pistón, N. \& Pugnaire, F.I. 2016. Functional plant types drive plant interactions in a Mediterranean mountain range. Frontiers in Plant Science 7.

Maestre, F.T., Callaway, R.M., Valladares, F. \& Lortie, C.J. 2009. Refining the stress-gradient hypothesis for competition and facilitation in plant communities. Journal of Ecology 97: 199-205.

Maestre, F.T., Valladares, F. \& Reynolds, J.F. 2005. Is the change of plant-plant interactions with abiotic stress predictable? A meta-analysis of field results in arid environments. Journal of Ecology 93: 748-757.

Maestre, F.T. \& Cortina, J. 2004. Do positive interactions increase with abiotic stress? A test from a semi-arid steppe. Proceedings of the Royal Society of London. Series B: Biological Sciences 271: S331.

Maestre, F.T., Bautista, S. \& Cortina, J. 2003. Positive, negative, and net effects in grass-shrub interactions in Mediterranean semiarid grasslands. Ecology 84: 3186-3197.

Martínez, M.L. 2003. Facilitation of seedling establishment by an endemic shrub in tropical coastal sand dunes. Plant Ecology 168: 333-345.

McKinney, A.M. \& Goodell, K. 2010. Shading by invasive shrub reduces seed production and pollinator services in a native herb. Biological Invasions 12: 2751-2763.

Metz, J. \& Tielbörger, K. 2016. Spatial and temporal aridity gradients provide poor proxies for plant-plant interactions under climate change: a large-scale experiment. Functional Ecology 30: 20-29.

Michalet, R. \& Pugnaire, F.I. 2016. Facilitation in communities: underlying mechanisms, community and ecosystem implications. Functional Ecology 30: 3-9.

Michalet, R., Le Bagousse-Pinguet, Y., Maalouf, J.-P. \& Lortie, C.J. 2014. Two alternatives to the stress-gradient hypothesis at the edge of life: the collapse of facilitation and the switch from facilitation to competition. Journal of Vegetation Science 25: 609-613.

Michalet, R., Brooker, R.W., Cavieres, L.A., Kikvidze, Z., Lortie, C.J., Pugnaire, F.I., ValienteBanuet, A. \& Callaway, R.M. 2006. Do biotic interactions shape both sides of the humped-back model of species richness in plant communities? Ecology Letters 9: 767773.

Miller, T.E., Gornish, E.S. \& Buckley, H.L. 2010. Climate and coastal dune vegetation: disturbance, recovery, and succession. Plant Ecology 206: 97.

Miriti, M.N. 2006. Ontogenetic shift from facilitation to competition in a desert shrub. Journal of Ecology 94: 973-979. 
Molina-Montenegro, M.A., Badano, E.I. \& Cavieres, L.A. 2008. Positive interactions among plant species for pollinator service: assessing the 'magnet species' concept with invasive species. Oikos 117: 1833-1839.

Nakagawa, S., Noble, D.W.A., Senior, A.M. \& Lagisz, M. 2017. Meta-evaluation of metaanalysis: ten appraisal questions for biologists. BMC Biology 15: 18.

Nakagawa, S. \& Santos, E.S.A. 2012. Methodological issues and advances in biological metaanalysis. Evolutionary Ecology 26: 1253-1274.

Navas, M. \& Violle, C. 2009. Plant traits related to competition: how do they shape the functional diversity of communities? Community Ecology 10: 131-137.

Niinemets, Ü. 2010. Responses of forest trees to single and multiple environmental stresses from seedlings to mature plants: Past stress history, stress interactions, tolerance and acclimation. Forest Ecology and Management 260: 1623-1639.

Oosting, H.J. \& Billings, W.D. 1942. Factors effecting vegetational zonation on coastal dunes. Ecology 23: 131-142.

Orwin, R.G. 1983. A fail-safe $\mathrm{N}$ for effect size in meta-analysis. Journal of Educational Statistics 8: 157-159.

Padilla, F.M. \& Pugnaire, F.I. 2006. The role of nurse plants in the restoration of degraded environments. Frontiers in Ecology and the Environment 4: 196-202.

Pistón, N., Armas, C., Schöb, C., Macek, P. \& Pugnaire, F.I. 2015. Phylogenetic distance among beneficiary species in a cushion plant species explains interaction outcome. Oikos 124: $1354-1359$.

Psuty, N.P. 2008. The coastal foredune: A morphological basis for regional coastal dune development. In Coastal dunes: ecology and conservation (eds M.L. Martínez \& N.P. Psuty), pp. 11-27. Springer, Berlin, Heidelberg.

Quero, J.L., Gómez-Aparicio, L., Zamora, R. \& Maestre, F.T. 2008. Shifts in the regeneration niche of an endangered tree (Acer opalus ssp. granatense) during ontogeny: Using an ecological concept for application. Basic and Applied Ecology 9: 635-644.

Quintessa. 2017. Graph Grabber 2.0. URL https://www.quintessa.org/software/downloadsand-demos/graph-grabber-2.0

R Development Core Team. 2018. R: A language and environment for statistical computing, $\mathrm{R}$ Foundation for Statistical Computing, Vienna, Austria. URL https://www.Rproject.org/.

Reflora. 2017. Plantas do Brasil 2020. URL: http://reflora.jbrj.gov.br/reflora/listaBrasil/Cons 
ultaPublicaUC/ConsultaPublicaUC.do\#CondicaoTaxonCP

Reich, P.B., Wright, I.J., Cavender-Bares, J., Craine, J.M., Oleksyn, J., Westoby, M. \& Walters, M.B. 2003. The evolution of plant functional variation: traits, spectra, and strategies. International Journal of Plant Sciences 164: S143-S164.

Reisman-Berman, O. 2007. Age-related change in canopy traits shifts conspecific facilitation to interference in a semi-arid shrubland. Ecography 30: 459-470.

Rey, P.J., Alcántara, J.M., Manzaneda, A.J. \& Sánchez-Lafuente, A.M. 2016. Facilitation contributes to Mediterranean woody plant diversity but does not shape the diversityproductivity relationship along aridity gradients. New Phytologist 211: 464-476.

Sage, R.F. 2017. A portrait of the C4 photosynthetic family on the 50th anniversary of its discovery: species number, evolutionary lineages, and Hall of Fame. Journal of Experimental Botany 67: 4039-4056.

Scarano, F.R. 2002. Structure, function and floristic relationships of plant communities in stressful habitats marginal to the Brazilian Atlantic Rainforest. Annals of Botany 90: 517524.

Schiffers, K. \& Tielbörger, K. 2006. Ontogenetic shifts in interactions among annual plants. Journal of Ecology 94: 336-341.

Schöb, C., Butterfield, B.J. \& Pugnaire, F.I. 2012. Foundation species influence trait-based community assembly. New Phytologist 196: 824-834.

Shumway, S.W. 2000. Facilitative effects of a sand dune shrub on species growing beneath the shrub canopy. Oecologia 124: 138-148.

Siteur, K., Mao, J., Nierop, K.G.J., Rietkerk, M., Dekker, S.C. \& Eppinga, M.B. 2016. Soil water repellency: a potential driver of vegetation dynamics in coastal dunes. Ecosystems 19: $1210-1224$.

Soliveres, S., Smit, C. \& Maestre, F.T. 2015. Moving forward on facilitation research: response to changing environments and effects on the diversity, functioning and evolution of plant communities. Biological Reviews 90: 297-313.

Soliveres, S. \& Maestre, F.T. 2014. Plant-plant interactions, environmental gradients and plant diversity: A global synthesis of community-level studies. Perspectives in Plant Ecology, Evolution and Systematics 16: 154-163.

Sterne, J.A.C. \& Egger, M. 2005. Regression methods to detect publication and other bias in meta-analysis. In Publication bias in meta-analysis: prevention, assessment and 
adjustments (eds H.R. Rothstein, A.J. Sutton \& M. Borenstein M), pp. 99-110. John Wiley \& Sons, Chichester, UK.

Stinca, A., Chirico, G.B., Incerti, G. \& Bonanomi, G. 2015. Regime shift by an exotic nitrogenfixing shrub mediates plant facilitation in primary succession. PLOS ONE 10: e0123128.

Teixeira, L.H., Weisser, W. \& Ganade, G. 2016. Facilitation and sand burial affect plant survival during restoration of a tropical coastal sand dune degraded by tourist cars. Restoration Ecology 24: 390-397.

Traveset, A., Riera, N. \& Mas, R.E. 2001. Passage through bird guts causes interspecific differences in seed germination characteristics. Functional Ecology 15: 669-675.

van der Waal, C., de Kroon, H., de Boer, W.F., Heitkönig, I.M.A., Skidmore, A.K., de Knegt, H.J., van Langevelde, F., van Wieren, S.E., Grant, R.C., Page, B.R., Slotow, R., Kohi, E.M., Mwakiwa, E. \& Prins, H.H.T. 2009. Water and nutrients alter herbaceous competitive effects on tree seedlings in a semi-arid savanna. Journal of Ecology 97: 430439.

Verdú, M., Gómez-Aparicio, L. \& Valiente-Banuet, A. 2012. Phylogenetic relatedness as a tool in restoration ecology: a meta-analysis. Proceedings of the Royal Society B: Biological Sciences 279: 1761.

Verdú, M., Villar-Salvador, P. \& García-Fayos, P. 2004. Gender effects on the post-facilitation performance of two dioecious Juniperus species. Functional Ecology 18: 87-93.

Verwijmeren, M., Rietkerk, M., Wassen, M.J. \& Smit, C. 2013. Interspecific facilitation and critical transitions in arid ecosystems. Oikos 122: 341-347.

Viechtbauer, W. 2010. Conducting Meta-Analyses in R with the metafor Package. 2010 36: 48.

Viechtbauer, W. \& Cheung, M.W.L. 2010. Outlier and influence diagnostics for meta-analysis. Research Synthesis Methods 1: 112-125.

Wickham, H. 2016. ggplot2: Elegant Graphics for Data Analysis, Springer International Publishing.

Wilson \& Sykes. 1999. Is zonation on coastal sand dunes determined primarily by sand burial or by salt spray? A test in New Zealand dunes. Ecology Letters 2: 233-236.

Wright, A., Schnitzer, S.A. \& Reich, P.B. 2014. Living close to your neighbors: the importance of both competition and facilitation in plant communities. Ecology 95: 2213-2223.

Wright, I.J., Reich, P.B., Westoby, M., Ackerly, D.D., Baruch, Z., Bongers, F., CavenderBares, J., Chapin, T., Cornelissen, J.H.C., Diemer, M., Flexas, J., Garnier, E., Groom, P.K., Gulias, J., Hikosaka, K., Lamont, B.B., Lee, T., Lee, W., Lusk, C., Midgley, J.J., 
Navas, M.-L., Niinemets, Ü., Oleksyn, J., Osada, N., Poorter, H., Poot, P., Prior, L., Pyankov, V.I., Roumet, C., Thomas, S.C., Tjoelker, M.G., Veneklaas, E.J. \& Villar, R. 2004. The worldwide leaf economics spectrum. Nature 428: 821.

Zahawi, R.A., Holl, K.D., Cole, R.J. \& Reid, J.L. 2013. Testing applied nucleation as a strategy to facilitate tropical forest recovery. Journal of Applied Ecology 50: 88-96.

Zhang, L., Mi, X. \& Shao, H. 2016. Phylogenetic relatedness influences plant interspecific interactions across stress levels in coastal ecosystems: a meta-analysis. Estuaries and Coasts 39: 1669-1678.

Zomer, R.J., Trabucco, A., Bossio, D.A. \& Verchot, L.V. 2008. Climate change mitigation: A spatial analysis of global land suitability for clean development mechanism afforestation and reforestation. Agriculture, Ecosystems \& Environment 126: 67-80.

Zomer, R.J., Bossio, D.A., Trabucco, A., Yuanjie, L., Gupta, D.C. \& Singh, V.P. 2007. Trees and water: smallholder agroforestry on irrigated lands in Northern India, International Water Management Institute. 


\section{SUPPORTING INFORMATION}

Table S1. Table containing all the information used in this study. For each theoretical performance variable, we specify the identity of effect size, the publication from which we extracted data, information about the study site, interacting species and effect sizes. TPV: theoretical performance variable (A - abundance, S - survival, G - growth, R - reproduction); ES: effect size identity; Pub: Publication identity (see Appendix S1); Lat: latitude of study site; Lon: longitude of study site; GAI: value of global aridity index for the study site; Grad: part of the dune gradient where the study was conducted ( 1 for primary dunes; 2 for scrub; 3 for back dunes, and 4 for not specified); Species: code with the two first letters of genus name and two first letters of specific epithet (see complete names of species in Table S2); OPV: operational performance variable; Var: variance of effect size.

\begin{tabular}{|c|c|c|c|c|c|c|c|c|c|c|c|c|c|c|}
\hline \multirow[b]{2}{*}{ TPV } & \multirow[b]{2}{*}{$\mathbf{E S}$} & \multirow[b]{2}{*}{ Pub } & \multirow[b]{2}{*}{ Lat } & \multirow[b]{2}{*}{ Lon } & \multirow[b]{2}{*}{ GAI } & \multirow[b]{2}{*}{ Grad } & \multicolumn{2}{|c|}{ Neighbor } & \multicolumn{3}{|c|}{ Target } & \multirow[b]{2}{*}{ OPV } & \multirow[b]{2}{*}{ Hedge's d } & \multirow[b]{2}{*}{ Var } \\
\hline & & & & & & & Species & Life-form & Species & Life-form & $\begin{array}{c}\text { Ontogenetic } \\
\text { stage } \\
\end{array}$ & & & \\
\hline A & 1 & {$[2]$} & 43.87 & 12.98 & 0.83 & 2 & Mema & shrub & Lopu & grass & several & density & 1.33 & 0.21 \\
\hline A & 2 & {$[4]$} & 40.58 & -74.09 & 1.18 & 1 & Ambr & grass & Trpu & grass & several & density & -0.07 & 0.01 \\
\hline A & 3 & {$[4]$} & 40.58 & -74.09 & 1.18 & 1 & Ambr & grass & Cetr & grass & several & density & -0.59 & 0.01 \\
\hline A & 4 & {$[4]$} & 40.58 & -74.09 & 1.18 & 1 & Ambr & grass & Hesu & forb & several & density & -0.37 & 0.08 \\
\hline A & 5 & [5] & 38.30 & -123.05 & 0.94 & 2 & Luch & shrub & Clpe & forb & several & density & 2.09 & 0.13 \\
\hline A & 6 & [5] & 38.30 & -123.05 & 0.94 & 2 & Erer & shrub & Clpe & forb & several & density & 2.40 & 0.15 \\
\hline A & 7 & [5] & 38.30 & -123.05 & 0.94 & 2 & Luch & shrub & Brdi & grass & several & density & 0.39 & 0.09 \\
\hline $\mathrm{A}$ & 8 & [5] & 38.30 & -123.05 & 0.94 & 2 & Erer & shrub & Brdi & grass & several & density & 0.17 & 0.08 \\
\hline $\mathrm{A}$ & 9 & [5] & 38.30 & -123.05 & 0.94 & 2 & Luch & shrub & Vubr & grass & several & density & -1.24 & 0.10 \\
\hline $\mathrm{A}$ & 10 & {$[5]$} & 38.30 & -123.05 & 0.94 & 2 & Erer & shrub & Vubr & grass & several & density & -0.74 & 0.09 \\
\hline A & 11 & [7] & 40.95 & 8.83 & 0.59 & 1 & Locy & sub shrub & Arpu & sub shrub & several & plant coverage & -0.14 & 0.25 \\
\hline A & 12 & [7] & 40.95 & 8.83 & 0.59 & 1 & Arpu & sub shrub & Locy & sub shrub & several & plant coverage & -0.28 & 0.25 \\
\hline A & 13 & [7] & 40.95 & 8.83 & 0.59 & 2 & Locy & sub shrub & Arpu & sub shrub & several & plant coverage & -0.74 & 0.27 \\
\hline A & 14 & [7] & 40.95 & 8.83 & 0.59 & 2 & Caac & forb & Arpu & sub shrub & several & plant coverage & -0.86 & 0.28 \\
\hline A & 15 & [7] & 40.95 & 8.83 & 0.59 & 2 & Arpu & sub shrub & Locy & sub shrub & several & plant coverage & -0.66 & 0.27 \\
\hline $\mathrm{A}$ & 16 & [7] & 40.95 & 8.83 & 0.59 & 2 & Caac & forb & Locy & sub shrub & several & plant coverage & 0.36 & 0.26 \\
\hline
\end{tabular}


Table S1 (cont.)

\begin{tabular}{|c|c|c|c|c|c|c|c|c|c|c|c|c|c|c|}
\hline \multirow[b]{2}{*}{ TPV } & \multirow[b]{2}{*}{ ES } & \multirow[b]{2}{*}{ Pub } & \multirow[b]{2}{*}{ Lat } & \multirow[b]{2}{*}{ Lon } & \multirow[b]{2}{*}{ GAI } & \multirow[b]{2}{*}{ Grad } & \multicolumn{2}{|c|}{ Neighbor } & \multicolumn{3}{|c|}{ Target } & \multirow[b]{2}{*}{ OPV } & \multirow[b]{2}{*}{ Hedge's d } & \multirow[b]{2}{*}{ Var } \\
\hline & & & & & & & Species & Life-form & Species & Life-form & $\begin{array}{c}\text { Ontogenetic } \\
\text { stage }\end{array}$ & & & \\
\hline A & 17 & [7] & 40.95 & 8.83 & 0.59 & 2 & Arpu & sub shrub & Caac & forb & several & plant coverage & 0.23 & 0.25 \\
\hline A & 18 & [7] & 40.95 & 8.83 & 0.59 & 2 & Locy & sub shrub & Caac & forb & several & plant coverage & -0.43 & 0.26 \\
\hline $\mathrm{A}$ & 19 & [7] & 40.95 & 8.83 & 0.59 & 2 & Caac & forb & Arpu & sub shrub & several & plant coverage & 0.60 & 0.26 \\
\hline $\mathrm{A}$ & 20 & [7] & 40.95 & 8.83 & 0.59 & 2 & Piha & tree & Arpu & sub shrub & several & plant coverage & -0.61 & 0.26 \\
\hline A & 21 & [7] & 40.95 & 8.83 & 0.59 & 2 & Arpu & sub shrub & Caac & forb & several & plant coverage & -0.86 & 0.28 \\
\hline A & 22 & [7] & 40.95 & 8.83 & 0.59 & 2 & Piha & tree & Caac & forb & several & plant coverage & -0.03 & 0.25 \\
\hline A & 23 & [7] & 40.95 & 8.83 & 0.59 & 2 & Arpu & sub shrub & Piha & tree & several & plant coverage & -0.37 & 0.26 \\
\hline A & 24 & [7] & 40.95 & 8.83 & 0.59 & 2 & Caac & forb & Piha & tree & several & plant coverage & -0.41 & 0.26 \\
\hline A & 25 & {$[10]$} & 30.92 & 31.50 & 0.03 & 3 & Acsa & tree & Aebi & grass & several & relative density & 0.25 & 0.07 \\
\hline $\mathrm{A}$ & 26 & {$[10]$} & 30.92 & 31.50 & 0.03 & 3 & Acsa & tree & Rupi & forb & several & relative density & 0.23 & 0.07 \\
\hline $\mathrm{A}$ & 27 & {$[10]$} & 30.92 & 31.50 & 0.03 & 3 & Acsa & tree & Brdi & grass & several & relative density & 0.15 & 0.07 \\
\hline $\mathrm{A}$ & 28 & {$[10]$} & 30.92 & 31.50 & 0.03 & 3 & Acsa & tree & Erla & forb & several & relative density & 0.10 & 0.07 \\
\hline $\mathrm{A}$ & 29 & {$[10]$} & 30.92 & 31.50 & 0.03 & 3 & Acsa & tree & Mecr & forb & several & relative density & -0.40 & 0.07 \\
\hline $\mathrm{A}$ & 30 & {$[10]$} & 30.92 & 31.50 & 0.03 & 3 & Acsa & tree & Algr & sub shrub & several & relative density & -0.25 & 0.07 \\
\hline $\mathrm{A}$ & 31 & {$[10]$} & 30.92 & 31.50 & 0.03 & 3 & Acsa & tree & Anhu & forb & several & relative density & -0.45 & 0.07 \\
\hline A & 32 & {$[10]$} & 30.92 & 31.50 & 0.03 & 3 & Acsa & tree & Arma & shrub & several & relative density & -0.38 & 0.07 \\
\hline A & 33 & {$[10]$} & 30.92 & 31.50 & 0.03 & 3 & Acsa & tree & Ashi & forb & several & relative density & 0.33 & 0.07 \\
\hline A & 34 & {$[10]$} & 30.92 & 31.50 & 0.03 & 3 & Acsa & tree & Avfa & grass & several & relative density & -0.27 & 0.07 \\
\hline $\mathrm{A}$ & 35 & {$[10]$} & 30.92 & 31.50 & 0.03 & 3 & Acsa & tree & Bain & forb & several & relative density & -0.68 & 0.07 \\
\hline $\mathrm{A}$ & 36 & {$[10]$} & 30.92 & 31.50 & 0.03 & 3 & Acsa & tree & Bevu & forb & several & relative density & -0.25 & 0.07 \\
\hline A & 37 & {$[10]$} & 30.92 & 31.50 & 0.03 & 3 & Acsa & tree & Brto & forb & several & relative density & -0.25 & 0.07 \\
\hline A & 38 & {$[10]$} & 30.92 & 31.50 & 0.03 & 3 & Acsa & tree & Cama & forb & several & relative density & -0.81 & 0.07 \\
\hline A & 39 & {$[10]$} & 30.92 & 31.50 & 0.03 & 3 & Acsa & tree & Capy & forb & several & relative density & 0.40 & 0.07 \\
\hline A & 40 & [10] & 30.92 & 31.50 & 0.03 & 3 & Acsa & tree & Cate & forb & several & relative density & -0.25 & 0.07 \\
\hline A & 41 & [10] & 30.92 & 31.50 & 0.03 & 3 & Acsa & tree & Chmu & forb & several & relative density & 0.09 & 0.07 \\
\hline A & 42 & {$[10]$} & 30.92 & 31.50 & 0.03 & 3 & Acsa & tree & Cume & grass & several & relative density & 0.68 & 0.07 \\
\hline A & 43 & {$[10]$} & 30.92 & 31.50 & 0.03 & 3 & Acsa & tree & Cyda & grass & several & relative density & 0.46 & 0.07 \\
\hline
\end{tabular}


Table S1 (cont.)

\begin{tabular}{|c|c|c|c|c|c|c|c|c|c|c|c|c|c|c|}
\hline \multirow[b]{2}{*}{ TPV } & \multirow[b]{2}{*}{ ES } & \multirow[b]{2}{*}{ Pub } & \multirow[b]{2}{*}{ Lat } & \multirow[b]{2}{*}{ Lon } & \multirow[b]{2}{*}{ GAI } & \multirow[b]{2}{*}{ Grad } & \multicolumn{2}{|c|}{ Neighbor } & \multicolumn{3}{|c|}{ Target } & \multirow[b]{2}{*}{ OPV } & \multirow[b]{2}{*}{ Hedge's d } & \multirow[b]{2}{*}{ Var } \\
\hline & & & & & & & Species & Life-form & Species & Life-form & $\begin{array}{c}\text { Ontogenetic } \\
\text { stage }\end{array}$ & & & \\
\hline A & 44 & [10] & 30.92 & 31.50 & 0.03 & 3 & Acsa & tree & Cyca & grass & several & relative density & -0.25 & 0.07 \\
\hline A & 45 & {$[10]$} & 30.92 & 31.50 & 0.03 & 3 & Acsa & tree & Dali & forb & several & relative density & -0.25 & 0.07 \\
\hline $\mathrm{A}$ & 46 & {$[10]$} & 30.92 & 31.50 & 0.03 & 3 & Acsa & tree & Ecsp & forb & several & relative density & 0.12 & 0.07 \\
\hline $\mathrm{A}$ & 47 & {$[10]$} & 30.92 & 31.50 & 0.03 & 3 & Acsa & tree & Ecan & forb & several & relative density & -0.25 & 0.07 \\
\hline $\mathrm{A}$ & 48 & [10] & 30.92 & 31.50 & 0.03 & 3 & Acsa & tree & Emsp & forb & several & relative density & -0.35 & 0.07 \\
\hline A & 49 & {$[10]$} & 30.92 & 31.50 & 0.03 & 3 & Acsa & tree & Hast & forb & several & relative density & -0.75 & 0.07 \\
\hline A & 50 & {$[10]$} & 30.92 & 31.50 & 0.03 & 3 & Acsa & tree & Homu & grass & several & relative density & 0.54 & 0.07 \\
\hline A & 51 & [10] & 30.92 & 31.50 & 0.03 & 3 & Acsa & tree & Ifsp & forb & several & relative density & -0.85 & 0.07 \\
\hline A & 52 & [10] & 30.92 & 31.50 & 0.03 & 3 & Acsa & tree & Lamu & forb & several & relative density & -0.60 & 0.07 \\
\hline A & 53 & [10] & 30.92 & 31.50 & 0.03 & 3 & Acsa & tree & Lesa & forb & several & relative density & -0.25 & 0.07 \\
\hline A & 54 & {$[10]$} & 30.92 & 31.50 & 0.03 & 3 & Acsa & tree & Lope & grass & several & relative density & 0.13 & 0.07 \\
\hline A & 55 & {$[10]$} & 30.92 & 31.50 & 0.03 & 3 & Acsa & tree & Locr & forb & several & relative density & -0.25 & 0.07 \\
\hline A & 56 & {$[10]$} & 30.92 & 31.50 & 0.03 & 3 & Acsa & tree & Loha & forb & several & relative density & -0.55 & 0.07 \\
\hline A & 57 & {$[10]$} & 30.92 & 31.50 & 0.03 & 3 & Acsa & tree & Mapa & forb & several & relative density & 0.25 & 0.07 \\
\hline A & 58 & {$[10]$} & 30.92 & 31.50 & 0.03 & 3 & Acsa & tree & Mein1 & forb & several & relative density & -0.25 & 0.07 \\
\hline A & 59 & {$[10]$} & 30.92 & 31.50 & 0.03 & 3 & Acsa & tree & Mein2 & forb & several & relative density & -0.25 & 0.07 \\
\hline A & 60 & {$[10]$} & 30.92 & 31.50 & 0.03 & 3 & Acsa & tree & Meno & forb & several & relative density & -0.51 & 0.07 \\
\hline A & 61 & {$[10]$} & 30.92 & 31.50 & 0.03 & 3 & Acsa & tree & Moci & sub shrub & several & relative density & -0.25 & 0.07 \\
\hline A & 62 & {$[10]$} & 30.92 & 31.50 & 0.03 & 3 & Acsa & tree & Onse & forb & several & relative density & -0.28 & 0.07 \\
\hline A & 63 & {$[10]$} & 30.92 & 31.50 & 0.03 & 3 & Acsa & tree & Page & grass & several & relative density & -0.25 & 0.07 \\
\hline A & 64 & {$[10]$} & 30.92 & 31.50 & 0.03 & 3 & Acsa & tree & Plsq & forb & several & relative density & -0.42 & 0.07 \\
\hline A & 65 & {$[10]$} & 30.92 & 31.50 & 0.03 & 3 & Acsa & tree & Poeq & forb & several & relative density & -0.25 & 0.07 \\
\hline A & 66 & {$[10]$} & 30.92 & 31.50 & 0.03 & 3 & Acsa & tree & Pomo & grass & several & relative density & -0.25 & 0.07 \\
\hline A & 67 & {$[10]$} & 30.92 & 31.50 & 0.03 & 3 & Acsa & tree & Reti & forb & several & relative density & 0.22 & 0.07 \\
\hline A & 68 & {$[10]$} & 30.92 & 31.50 & 0.03 & 3 & Acsa & tree & Saka & forb & several & relative density & 0.30 & 0.07 \\
\hline A & 69 & {$[10]$} & 30.92 & 31.50 & 0.03 & 3 & Acsa & tree & Segl & forb & several & relative density & -0.51 & 0.07 \\
\hline A & 70 & {$[10]$} & 30.92 & 31.50 & 0.03 & 3 & Acsa & tree & Sisu & forb & several & relative density & 0.14 & 0.07 \\
\hline A & 71 & [10] & 30.92 & 31.50 & 0.03 & 3 & Acsa & tree & Sool & forb & several & relative density & -0.44 & 0.07 \\
\hline
\end{tabular}


Table S1 (cont.)

\begin{tabular}{|c|c|c|c|c|c|c|c|c|c|c|c|c|c|c|}
\hline \multirow[b]{2}{*}{ TPV } & \multirow[b]{2}{*}{ ES } & \multirow[b]{2}{*}{ Pub } & \multirow[b]{2}{*}{ Lat } & \multirow[b]{2}{*}{ Lon } & \multirow[b]{2}{*}{ GAI } & \multirow[b]{2}{*}{ Grad } & \multicolumn{2}{|c|}{ Neighbor } & \multicolumn{3}{|c|}{ Target } & \multirow[b]{2}{*}{ OPV } & \multirow[b]{2}{*}{ Hedge's d } & \multirow[b]{2}{*}{ Var } \\
\hline & & & & & & & Species & Life-form & Species & Life-form & $\begin{array}{c}\text { Ontogenetic } \\
\text { stage }\end{array}$ & & & \\
\hline A & 72 & {$[10]$} & 30.92 & 31.50 & 0.03 & 3 & Acsa & tree & Spma & forb & several & relative density & -0.25 & 0.07 \\
\hline $\mathrm{A}$ & 73 & {$[10]$} & 30.92 & 31.50 & 0.03 & 3 & Acsa & tree & Tase & tree & several & relative density & -0.25 & 0.07 \\
\hline $\mathrm{A}$ & 74 & {$[10]$} & 30.92 & 31.50 & 0.03 & 3 & Acsa & tree & Urpi & forb & several & relative density & -0.25 & 0.07 \\
\hline $\mathrm{A}$ & 75 & {$[10]$} & 30.92 & 31.50 & 0.03 & 3 & Acsa & tree & Zyae & shrub & several & relative density & -0.68 & 0.07 \\
\hline $\mathrm{A}$ & 76 & {$[10]$} & 30.92 & 31.50 & 0.03 & 3 & Acsa & tree & Teal & sub shrub & several & relative density & -0.31 & 0.07 \\
\hline A & 77 & {$[14]$} & 55.28 & -77.75 & 1.43 & 1 & Hope & forb & Lemo & grass & seedling & density & 0.41 & 0.08 \\
\hline A & 78 & {$[15]$} & 65.03 & 24.62 & 1.03 & 1 & Emni & shrub & Pisy & tree & seedling & density & 0.13 & 0.01 \\
\hline A & 79 & {$[15]$} & 65.03 & 24.62 & 1.03 & 2 & Emni & shrub & Pisy & tree & seedling & density & 0.34 & 0.01 \\
\hline A & 80 & [16] & 37.67 & -75.67 & 0.98 & 2 & Juvi & tree & NI & woody & several & density & 0.81 & 0.17 \\
\hline A & 81 & {$[21]$} & 19.52 & -96.38 & 0.72 & 2 & Chch & shrub & Trsp & grass & adult & density & 0.98 & 0.26 \\
\hline A & 82 & [21] & 19.52 & -96.38 & 0.72 & 2 & Chch & shrub & Scsc & grass & adult & density & 0.00 & 0.22 \\
\hline A & 83 & {$[21]$} & 19.52 & -96.38 & 0.72 & 2 & Chch & shrub & NI & grass & seedling & density & -1.25 & 0.28 \\
\hline A & 84 & [21] & 19.52 & -96.38 & 0.72 & 2 & Chch & shrub & Trsp & grass & adult & density & 0.92 & 0.25 \\
\hline A & 85 & [21] & 19.52 & -96.38 & 0.72 & 2 & Chch & shrub & Scsc & grass & adult & density & -4.81 & 1.03 \\
\hline A & 86 & [21] & 19.52 & -96.38 & 0.72 & 2 & Chch & shrub & NI & grass & seedling & density & -0.54 & 0.23 \\
\hline A & 87 & [26] & 41.90 & -69.97 & 1.45 & 2 & Mype & shrub & Ambr & grass & adult & density & 0.65 & 0.11 \\
\hline A & 88 & [26] & 41.90 & -69.97 & 1.45 & 2 & Mype & shrub & Sose & forb & adult & density & -0.24 & 0.10 \\
\hline A & 89 & [26] & 41.90 & -69.97 & 1.45 & 2 & Mype & shrub & Ambr & grass & seedling & density & -0.12 & 0.08 \\
\hline A & 90 & [26] & 41.90 & -69.97 & 1.45 & 2 & Mype & shrub & Sose & forb & seedling & density & 0.96 & 0.09 \\
\hline A & 91 & [27] & 34.75 & 32.05 & 0.42 & 2 & Rera & shrub & NI & herb & seedling & density & -1.14 & 0.06 \\
\hline A & 92 & [27] & 34.75 & 32.05 & 0.42 & 2 & Rera & shrub & NI & herb & several & density & -1.80 & 0.14 \\
\hline A & 93 & [28] & 32.05 & 34.75 & 0.42 & 2 & Rera & shrub & Mapu & forb & seedling & density & -4.85 & 0.20 \\
\hline A & 94 & [28] & 32.05 & 34.75 & 0.42 & 2 & Rera & shrub & Plin & forb & seedling & density & -4.38 & 0.18 \\
\hline A & 95 & [28] & 32.05 & 34.75 & 0.42 & 2 & Rera & shrub & Posu & forb & seedling & density & -4.23 & 0.17 \\
\hline A & 96 & [28] & 32.05 & 34.75 & 0.42 & 2 & Rera & shrub & Arse & forb & seedling & density & -3.08 & 0.11 \\
\hline A & 97 & [28] & 32.05 & 34.75 & 0.42 & 2 & Rera & shrub & Deph & grass & seedling & density & -0.18 & 0.05 \\
\hline $\mathrm{A}$ & 98 & [28] & 32.05 & 34.75 & 0.42 & 2 & Rera & shrub & Crac & forb & seedling & density & -3.77 & 0.14 \\
\hline A & 99 & [28] & 32.05 & 34.75 & 0.42 & 2 & Rera & shrub & Rubu & forb & seedling & density & -3.42 & 0.13 \\
\hline
\end{tabular}


Table S1 (cont.)

\begin{tabular}{|c|c|c|c|c|c|c|c|c|c|c|c|c|c|c|}
\hline \multirow[b]{2}{*}{ TPV } & \multirow[b]{2}{*}{ ES } & \multirow[b]{2}{*}{ Pub } & \multirow[b]{2}{*}{ Lat } & \multirow[b]{2}{*}{ Lon } & \multirow[b]{2}{*}{ GAI } & \multirow[b]{2}{*}{ Grad } & \multicolumn{2}{|c|}{ Neighbor } & \multicolumn{3}{|c|}{ Target } & \multirow[b]{2}{*}{ OPV } & \multirow[b]{2}{*}{ Hedge's d } & \multirow[b]{2}{*}{ Var } \\
\hline & & & & & & & Species & Life-form & Species & Life-form & $\begin{array}{c}\text { Ontogenetic } \\
\text { stage }\end{array}$ & & & \\
\hline A & 100 & [28] & 32.05 & 34.75 & 0.42 & 2 & Rera & shrub & Fuju & forb & seedling & density & 3.00 & 0.11 \\
\hline A & 101 & [28] & 32.05 & 34.75 & 0.42 & 2 & Rera & shrub & Anar & forb & seedling & density & -0.89 & 0.06 \\
\hline A & 102 & [28] & 32.05 & 34.75 & 0.42 & 2 & Rera & shrub & Vahi & forb & seedling & density & 4.44 & 0.18 \\
\hline A & 103 & [28] & 32.05 & 34.75 & 0.42 & 2 & Rera & shrub & Trpa & forb & seedling & density & -3.86 & 0.15 \\
\hline A & 104 & [28] & 32.05 & 34.75 & 0.42 & 2 & Rera & shrub & Ifsp & forb & seedling & density & -2.68 & 0.10 \\
\hline$S$ & 1 & {$[1]$} & 36.68 & -2.70 & 0.23 & 2 & Juph & shrub & Juph & shrub & seedling & survival & 1.32 & 0.17 \\
\hline S & 2 & [1] & 36.68 & -2.70 & 0.23 & 2 & Juph & shrub & Pile & shrub & seedling & survival & 1.85 & 0.29 \\
\hline $\mathrm{S}$ & 3 & [1] & 36.68 & -2.70 & 0.23 & 2 & Pile & shrub & Juph & shrub & seedling & survival & 1.18 & 0.18 \\
\hline $\mathrm{S}$ & 4 & [1] & 36.68 & -2.70 & 0.23 & 2 & Pile & shrub & Pile & shrub & seedling & survival & 0.82 & 0.29 \\
\hline $\mathrm{S}$ & 5 & [1] & 36.68 & -2.70 & 0.23 & 2 & NI & shrub & Juph & shrub & adult & survival & -0.99 & 0.02 \\
\hline $\mathrm{S}$ & 6 & [1] & 36.68 & -2.70 & 0.23 & 2 & NI & shrub & Pile & shrub & adult & survival & -0.03 & 0.21 \\
\hline $\mathrm{S}$ & 7 & [3] & -25.20 & -44.28 & 1.82 & 2 & Guop & tree & Tebr & tree & seedling & survival & 0.17 & 0.20 \\
\hline $\mathrm{S}$ & 8 & [3] & -25.20 & -44.28 & 1.82 & 2 & Guop & tree & Tebr & tree & seedling & survival & 0.72 & 0.22 \\
\hline $\mathrm{S}$ & 9 & [3] & -25.20 & -44.28 & 1.82 & 2 & Guop & tree & Tebr & tree & seedling & survival & 0.03 & 0.20 \\
\hline$S$ & 10 & [7] & 40.95 & 8.83 & 0.59 & 1 & Locy & sub shrub & Locy & sub shrub & seedling & survival & 0.00 & 734.65 \\
\hline$S$ & 11 & [7] & 40.95 & 8.83 & 0.59 & 1 & Pama & forb & Pama & forb & seedling & survival & 4.21 & 367.71 \\
\hline $\mathrm{S}$ & 12 & [7] & 40.95 & 8.83 & 0.59 & 2 & Locy & sub shrub & Locy & sub shrub & seedling & survival & 0.00 & 0.77 \\
\hline $\mathrm{S}$ & 13 & [7] & 40.95 & 8.83 & 0.59 & 2 & Pama & forb & Pama & forb & seedling & survival & 0.00 & 734.65 \\
\hline $\mathrm{S}$ & 14 & [7] & 40.95 & 8.83 & 0.59 & 2 & Arpu & sub shrub & Arpu & sub shrub & seedling & survival & -0.75 & 0.21 \\
\hline $\mathrm{S}$ & 15 & [7] & 40.95 & 8.83 & 0.59 & 3 & Arpu & sub shrub & Arpu & sub shrub & seedling & survival & -0.16 & 0.20 \\
\hline $\mathrm{S}$ & 16 & [9] & 34.68 & -120.60 & 0.32 & 1 & NI & grass & Caed & forb & seedling & survival & 0.35 & 0.43 \\
\hline $\mathrm{S}$ & 17 & [9] & 34.68 & -120.60 & 0.32 & 2 & NI & shrub & Caed & forb & seedling & survival & -1.29 & 0.55 \\
\hline$S$ & 18 & [9] & 34.68 & -120.60 & 0.32 & 1 & NI & grass & Caed & forb & adult & survival & 4.67 & 367.53 \\
\hline S & 19 & [9] & 34.68 & -120.60 & 0.32 & 2 & NI & shrub & Caed & forb & adult & survival & -1.03 & 0.17 \\
\hline$S$ & 20 & [9] & 34.68 & -120.60 & 0.32 & 2 & NI & shrub & Caed & forb & adult & survival & -0.51 & 0.16 \\
\hline$S$ & 21 & [9] & 34.68 & -120.60 & 0.32 & 1 & NI & grass & Caed & forb & adult & survival & 0.00 & 0.46 \\
\hline$S$ & 22 & [9] & 34.68 & -120.60 & 0.32 & 2 & NI & shrub & Caed & forb & adult & survival & 0.33 & 0.40 \\
\hline $\mathrm{S}$ & 23 & [9] & 34.68 & -120.60 & 0.32 & 2 & $\mathrm{NI}$ & shrub & Caed & forb & adult & survival & 0.00 & 734.69 \\
\hline
\end{tabular}


Table S1 (cont.)

\begin{tabular}{|c|c|c|c|c|c|c|c|c|c|c|c|c|c|c|}
\hline \multirow[b]{2}{*}{ TPV } & \multirow[b]{2}{*}{ ES } & \multirow[b]{2}{*}{ Pub } & \multirow[b]{2}{*}{ Lat } & \multirow[b]{2}{*}{ Lon } & \multirow[b]{2}{*}{ GAI } & \multirow[b]{2}{*}{ Grad } & \multicolumn{2}{|c|}{ Neighbor } & \multicolumn{3}{|c|}{ Target } & \multirow[b]{2}{*}{ OPV } & \multirow[b]{2}{*}{ Hedge's d } & \multirow[b]{2}{*}{ Var } \\
\hline & & & & & & & Species & Life-form & Species & Life-form & $\begin{array}{c}\text { Ontogenetic } \\
\text { stage }\end{array}$ & & & \\
\hline $\mathrm{S}$ & 24 & [12] & 44.72 & -1.23 & 1.20 & 1 & Elfa & grass & Elfa & grass & juvenile & survival & -0.23 & 0.34 \\
\hline $\mathrm{S}$ & 25 & {$[12]$} & 44.72 & -1.23 & 1.20 & 1 & Elfa & grass & Amar & grass & juvenile & survival & -0.21 & 0.34 \\
\hline $\mathrm{S}$ & 26 & {$[12]$} & 44.72 & -1.23 & 1.20 & 2 & Amar & grass & Elfa & grass & juvenile & survival & 1.51 & 0.47 \\
\hline S & 27 & {$[12]$} & 44.72 & -1.23 & 1.20 & 2 & Amar & grass & Amar & grass & juvenile & survival & 0.42 & 0.34 \\
\hline $\mathrm{S}$ & 28 & [12] & 44.72 & -1.23 & 1.20 & 2 & Amar & grass & Hest & forb & juvenile & survival & 0.29 & 0.34 \\
\hline $\mathrm{S}$ & 29 & [12] & 44.72 & -1.23 & 1.20 & 2 & Amar & grass & Coca & grass & juvenile & survival & 0.44 & 0.35 \\
\hline $\mathrm{S}$ & 30 & [12] & 44.72 & -1.23 & 1.20 & 2 & Hest & forb & Elfa & grass & juvenile & survival & 0.67 & 0.36 \\
\hline $\mathrm{S}$ & 31 & {$[12]$} & 44.72 & -1.23 & 1.20 & 2 & Hest & forb & Amar & grass & juvenile & survival & 0.02 & 0.33 \\
\hline $\mathrm{S}$ & 32 & [12] & 44.72 & -1.23 & 1.20 & 2 & Hest & forb & Hest & forb & juvenile & survival & -0.81 & 0.37 \\
\hline $\mathrm{S}$ & 33 & [12] & 44.72 & -1.23 & 1.20 & 2 & Hest & forb & Coca & grass & juvenile & survival & -0.56 & 0.35 \\
\hline $\mathrm{S}$ & 34 & [12] & 44.72 & -1.23 & 1.20 & 2 & Coca & grass & Elfa & grass & juvenile & survival & 0.84 & 0.38 \\
\hline $\mathrm{S}$ & 35 & [12] & 44.72 & -1.23 & 1.20 & 2 & Coca & grass & Amar & grass & juvenile & survival & -0.29 & 0.34 \\
\hline S & 36 & [12] & 44.72 & -1.23 & 1.20 & 2 & Coca & grass & Hest & forb & juvenile & survival & -0.16 & 0.33 \\
\hline $\mathrm{S}$ & 37 & [12] & 44.72 & -1.23 & 1.20 & 2 & Coca & grass & Coca & grass & juvenile & survival & -0.20 & 0.34 \\
\hline $\mathrm{S}$ & 38 & [16] & 37.67 & -75.67 & 0.98 & 2 & Juvi & tree & Saal & tree & seedling & survival & 0.00 & 734.63 \\
\hline $\mathrm{S}$ & 39 & [16] & 37.67 & -75.67 & 0.98 & 2 & Juvi & tree & Prse & tree & seedling & survival & 1.01 & 0.12 \\
\hline $\mathrm{S}$ & 40 & [17] & 38.32 & -123.05 & 0.91 & 2 & Erer & shrub & Brdi & forb & seedling & survival & 0.69 & 0.50 \\
\hline $\mathrm{S}$ & 41 & [18] & 44.72 & -1.23 & 1.20 & 2 & Hest & sub shrub & Feva & grass & adult & survival & 0.00 & 0.29 \\
\hline $\mathrm{S}$ & 42 & [18] & 44.72 & -1.23 & 1.20 & 2 & Hest & sub shrub & Sein & sub shrub & adult & survival & 0.48 & 0.30 \\
\hline $\mathrm{S}$ & 43 & [18] & 44.72 & -1.23 & 1.20 & 2 & Hest & sub shrub & Pama & forb & adult & survival & 0.12 & 0.29 \\
\hline $\mathrm{S}$ & 44 & [18] & 44.72 & -1.23 & 1.2 & 2 & Hest & sub shrub & Cisa & sub shrub & adult & survival & 0.62 & 0.30 \\
\hline $\mathrm{S}$ & 45 & [18] & 44.72 & -1.23 & 1.2 & 2 & Hest & sub shrub & Elfa & grass & adult & survival & 0.45 & 0.30 \\
\hline $\mathrm{S}$ & 46 & [18] & 44.72 & -1.23 & 1.20 & 2 & Hest & sub shrub & Oebi & forb & adult & survival & 0.42 & 0.29 \\
\hline $\mathrm{S}$ & 47 & [20] & 19.18 & -96.14 & 1.06 & 2 & Chch & shrub & Trsp & grass & seedling & survival & 5.88 & 367.34 \\
\hline S & 48 & [20] & 19.18 & -96.14 & 1.06 & 2 & Chch & shrub & Scsc & grass & seedling & survival & 5.61 & 367.35 \\
\hline $\mathrm{S}$ & 49 & [22] & 45.53 & -1.08 & 1.04 & 3 & NI & tree & Quro & tree & seedling & survival & 0.50 & 0.35 \\
\hline $\mathrm{S}$ & 50 & [22] & 45.53 & -1.08 & 1.04 & 3 & $\mathrm{NI}$ & tree & Quil & tree & seedling & survival & 0.70 & 0.36 \\
\hline $\mathrm{S}$ & 51 & [22] & 45.53 & -1.08 & 1.04 & 3 & NI & tree & Qusu & tree & seedling & survival & -0.49 & 0.35 \\
\hline
\end{tabular}


Table S1 (cont.)

\begin{tabular}{|c|c|c|c|c|c|c|c|c|c|c|c|c|c|c|}
\hline \multirow[b]{2}{*}{ TPV } & \multirow[b]{2}{*}{ ES } & \multirow[b]{2}{*}{ Pub } & \multirow[b]{2}{*}{ Lat } & \multirow[b]{2}{*}{ Lon } & \multirow[b]{2}{*}{ GAI } & \multirow[b]{2}{*}{ Grad } & \multicolumn{2}{|c|}{ Neighbor } & \multicolumn{3}{|c|}{ Target } & \multirow[b]{2}{*}{ OPV } & \multirow[b]{2}{*}{ Hedge's d } & \multirow[b]{2}{*}{ Var } \\
\hline & & & & & & & Species & Life-form & Species & Life-form & $\begin{array}{c}\text { Ontogenetic } \\
\text { stage }\end{array}$ & & & \\
\hline $\mathrm{S}$ & 52 & [22] & 43.68 & -1.42 & 1.49 & 3 & NI & tree & Quro & tree & seedling & survival & -0.69 & 0.36 \\
\hline S & 53 & {$[22]$} & 43.68 & -1.42 & 1.49 & 3 & NI & tree & Quil & tree & seedling & survival & -0.86 & 0.38 \\
\hline S & 54 & [22] & 43.68 & -1.42 & 1.49 & 3 & NI & tree & Qusu & tree & seedling & survival & -3.09 & 0.91 \\
\hline S & 55 & [23] & 37.20 & -7.12 & 0.44 & 2 & Remo & shrub & Thca & shrub & adult & survival & -1.09 & 0.56 \\
\hline S & 56 & {$[24]$} & 39.77 & 3.13 & 0.66 & 2 & Dagn & shrub & Dagn & shrub & seedling & survival & 1.04 & 0.11 \\
\hline S & 57 & [24] & 39.77 & 3.13 & 0.66 & 2 & Pile & shrub & Dagn & shrub & seedling & survival & 1.72 & 0.14 \\
\hline S & 58 & {$[24]$} & 39.77 & 3.13 & 0.66 & 2 & Ermu & shrub & Dagn & shrub & seedling & survival & 1.86 & 0.15 \\
\hline S & 59 & [24] & 39.77 & 3.13 & 0.66 & 2 & Dagn & shrub & Dagn & shrub & seedling & survival & 0.82 & 0.11 \\
\hline S & 60 & [24] & 39.77 & 3.13 & 0.66 & 2 & Pile & shrub & Dagn & shrub & seedling & survival & 0.80 & 0.11 \\
\hline S & 61 & [24] & 39.77 & 3.13 & 0.66 & 2 & Ermu & shrub & Dagn & shrub & seedling & survival & 1.11 & 0.12 \\
\hline S & 62 & [25] & 38.32 & -123.07 & 0.94 & 2 & Bapi & shrub & Luar & shrub & seedling & survival & 0.42 & 0.03 \\
\hline $\mathrm{S}$ & 63 & {$[25]$} & 38.32 & -123.07 & 0.94 & 2 & Amar & grass & Luar & shrub & seedling & survival & -0.72 & 0.06 \\
\hline $\mathrm{S}$ & 64 & [26] & 41.90 & -69.47 & 1.45 & 2 & Mype & shrub & Ambr & grass & seedling & survival & -0.27 & 0.08 \\
\hline $\mathrm{S}$ & 65 & [26] & 41.90 & -69.47 & 1.45 & 2 & Mype & shrub & Sose & forb & seedling & survival & -0.04 & 0.04 \\
\hline $\mathrm{G}$ & 1 & {$[1]$} & 36.68 & -2.70 & 0.23 & 2 & NI & shrub & Juph & shrub & adult & twig biomass & 1.08 & 0.26 \\
\hline $\mathrm{G}$ & 2 & {$[1]$} & 36.68 & -2.70 & 0.23 & 2 & NI & shrub & Pile & shrub & adult & twig biomass & 0.60 & 0.23 \\
\hline G & 3 & {$[2]$} & $\begin{array}{c}43.86 \\
-\end{array}$ & 12.98 & 0.83 & 2 & Mema & shrub & Lopu & grass & adult & $\begin{array}{l}\text { total biomass } \\
\text { aboveground }\end{array}$ & 1.21 & 0.20 \\
\hline G & 4 & [3] & $\begin{array}{c}25.20 \\
-\end{array}$ & -44.28 & 1.82 & 2 & Guop & tree & Tebr & tree & seedling & $\begin{array}{c}\text { biomass } \\
\text { aboveground }\end{array}$ & -1.02 & 0.22 \\
\hline G & 5 & [3] & $\begin{array}{c}25.20 \\
-\end{array}$ & -44.28 & 1.82 & 2 & Guop & tree & Tebr & tree & seedling & $\begin{array}{c}\text { biomass } \\
\text { aboveground }\end{array}$ & -0.89 & 0.04 \\
\hline G & 6 & {$[3]$} & 25.20 & -44.28 & 1.82 & 2 & Guop & tree & Tebr & tree & seedling & $\begin{array}{c}\text { biomass } \\
\text { aboveground }\end{array}$ & -0.34 & 0.03 \\
\hline G & 7 & {$[6]$} & 38.33 & -123.05 & 0.91 & 2 & Amar & grass & Ehca & grass & adult & $\begin{array}{l}\text { biomass } \\
\text { aboveground }\end{array}$ & 0.78 & 0.22 \\
\hline G & 8 & {$[6]$} & 38.33 & -123.05 & 0.91 & 2 & Bapi & shrub & Ehca & grass & adult & $\begin{array}{c}\text { biomass } \\
\text { aboveground }\end{array}$ & 1.21 & 0.25 \\
\hline G & 9 & {$[6]$} & 38.33 & -123.05 & 0.91 & 2 & Caed & forb & Ehca & grass & adult & $\begin{array}{l}\text { biomass } \\
\text { increment in }\end{array}$ & 0.04 & 0.20 \\
\hline $\mathrm{G}$ & 10 & {$[8]$} & 34.68 & -120.60 & 0.32 & 2 & Caed & forb & Erer & shrub & adult & canopy area & -1.29 & 0.34 \\
\hline
\end{tabular}


Table S1 (cont.)

\begin{tabular}{|c|c|c|c|c|c|c|c|c|c|c|c|c|c|c|}
\hline \multirow[b]{2}{*}{ TPV } & \multirow[b]{2}{*}{ ES } & \multirow[b]{2}{*}{ Pub } & \multirow[b]{2}{*}{ Lat } & \multirow[b]{2}{*}{ Lon } & \multirow[b]{2}{*}{ GAI } & \multirow[b]{2}{*}{ Grad } & \multicolumn{2}{|c|}{ Neighbor } & \multicolumn{3}{|c|}{ Target } & \multirow[b]{2}{*}{ OPV } & \multirow[b]{2}{*}{ Hedge's d } & \multirow[b]{2}{*}{ Var } \\
\hline & & & & & & & Species & Life-form & Species & Life-form & $\begin{array}{c}\text { Ontogenetic } \\
\text { stage }\end{array}$ & & & \\
\hline $\mathrm{G}$ & 11 & [8] & 34.68 & -120.60 & 0.32 & 2 & Caed & forb & Isme & shrub & adult & $\begin{array}{l}\text { reduction in } \\
\text { distance from } \\
\text { soil to first live } \\
\text { branch }\end{array}$ & -1.68 & 0.42 \\
\hline $\mathrm{G}$ & 12 & [9] & 34.68 & -120.60 & 0.32 & 1 & NI & grass & Caed & forb & adult & $\begin{array}{l}\text { biomass } \\
\text { aboveground }\end{array}$ & -0.03 & 0.105 \\
\hline G & 13 & [9] & 34.68 & -120.60 & 0.32 & 2 & NI & shrub & Caed & forb & adult & biomass & -0.82 & 0.26 \\
\hline $\mathrm{G}$ & 14 & [9] & 34.68 & -120.60 & 0.32 & 2 & NI & shrub & Caed & forb & adult & $\begin{array}{l}\text { biomass } \\
\text { aboveground }\end{array}$ & -0.24 & 0.17 \\
\hline $\mathrm{G}$ & 15 & [9] & 34.68 & -120.60 & 0.32 & 1 & NI & grass & Caed & forb & adult & $\begin{array}{c}\text { biomass } \\
\text { aboveground }\end{array}$ & 0.16 & 0.12 \\
\hline G & 16 & [9] & 34.68 & -120.60 & 0.32 & 2 & NI & shrub & Caed & forb & adult & $\begin{array}{c}\text { biomass } \\
\text { aboveground }\end{array}$ & -0.90 & 0.45 \\
\hline $\mathrm{G}$ & 17 & [9] & 34.68 & -120.60 & 0.32 & 2 & NI & shrub & Caed & forb & adult & $\begin{array}{c}\text { biomass } \\
\text { belowground }\end{array}$ & -1.30 & 0.27 \\
\hline $\mathrm{G}$ & 18 & [9] & 34.68 & -120.60 & 0.32 & 1 & NI & grass & Caed & forb & adult & $\begin{array}{c}\text { biomass } \\
\text { belowground }\end{array}$ & -0.34 & 0.11 \\
\hline G & 19 & [9] & 34.68 & -120.60 & 0.32 & 2 & NI & shrub & Caed & forb & adult & $\begin{array}{c}\text { biomass } \\
\text { belowground }\end{array}$ & -1.81 & 0.34 \\
\hline $\mathrm{G}$ & 20 & [9] & 34.68 & -120.60 & 0.32 & 2 & NI & shrub & Caed & forb & adult & biomass & -0.48 & 0.18 \\
\hline $\mathrm{G}$ & 21 & [12] & 44.72 & -1.23 & 1.20 & 1 & Elfa & grass & Elfa & grass & juvenile & total biomass & 0.65 & 0.15 \\
\hline $\mathrm{G}$ & 22 & [12] & 44.72 & -1.23 & 1.20 & 1 & Elfa & grass & Amar & grass & juvenile & total biomass & 1.98 & 1.18 \\
\hline $\mathrm{G}$ & 23 & [12] & 44.72 & -1.23 & 1.20 & 2 & Amar & grass & Elfa & grass & juvenile & total biomass & 1.62 & 0.28 \\
\hline $\mathrm{G}$ & 24 & [12] & 44.72 & -1.23 & 1.20 & 2 & Amar & grass & Amar & grass & juvenile & total biomass & 2.63 & 0.39 \\
\hline $\mathrm{G}$ & 25 & [12] & 44.72 & -1.23 & 1.20 & 2 & Amar & grass & Hest & forb & juvenile & total biomass & 0.04 & 0.34 \\
\hline $\mathrm{G}$ & 26 & [12] & 44.72 & -1.23 & 1.20 & 2 & Amar & grass & Coca & grass & juvenile & total biomass & -0.35 & 0.55 \\
\hline $\mathrm{G}$ & 27 & [12] & 44.72 & -1.23 & 1.20 & 2 & Hest & forb & Elfa & grass & juvenile & total biomass & 0.10 & 0.19 \\
\hline $\mathrm{G}$ & 26 & [12] & 44.72 & -1.23 & 1.20 & 2 & Amar & grass & Coca & grass & juvenile & total biomass & -0.35 & 0.55 \\
\hline $\mathrm{G}$ & 27 & [12] & 44.72 & -1.23 & 1.20 & 2 & Hest & forb & Elfa & grass & juvenile & total biomass & 0.10 & 0.19 \\
\hline $\mathrm{G}$ & 28 & [12] & 44.72 & -1.23 & 1.20 & 2 & Hest & forb & Amar & grass & juvenile & total biomass & 2.71 & 0.55 \\
\hline
\end{tabular}


Table S1 (cont.)

\begin{tabular}{|c|c|c|c|c|c|c|c|c|c|c|c|c|c|c|}
\hline \multirow[b]{2}{*}{ TPV } & \multirow[b]{2}{*}{ ES } & \multirow[b]{2}{*}{ Pub } & \multirow[b]{2}{*}{ Lat } & \multirow[b]{2}{*}{ Lon } & \multirow[b]{2}{*}{ GAI } & \multirow[b]{2}{*}{ Grad } & \multicolumn{2}{|c|}{ Neighbor } & \multicolumn{3}{|c|}{ Target } & \multirow[b]{2}{*}{ OPV } & \multirow[b]{2}{*}{ Hedge's d } & \multirow[b]{2}{*}{ Var } \\
\hline & & & & & & & Species & Life-form & Species & Life-form & $\begin{array}{c}\text { Ontogenetic } \\
\text { stage }\end{array}$ & & & \\
\hline G & 29 & [12] & 44.72 & -1.23 & 1.20 & 2 & Hest & forb & Hest & forb & juvenile & total biomass & 0.25 & 0.17 \\
\hline $\mathrm{G}$ & 30 & {$[12]$} & 44.72 & -1.23 & 1.20 & 2 & Hest & forb & Coca & grass & juvenile & total biomass & 0.21 & 0.16 \\
\hline $\mathrm{G}$ & 31 & {$[12]$} & 44.72 & -1.23 & 1.20 & 2 & Coca & grass & Elfa & grass & juvenile & total biomass & 0.26 & 0.20 \\
\hline $\mathrm{G}$ & 32 & {$[12]$} & 44.72 & -1.23 & 1.20 & 2 & Coca & grass & Amar & grass & juvenile & total biomass & 3.02 & 0.43 \\
\hline $\mathrm{G}$ & 33 & [12] & 44.72 & -1.23 & 1.20 & 2 & Coca & grass & Hest & forb & juvenile & total biomass & -0.28 & 0.21 \\
\hline G & 34 & {$[12]$} & 44.72 & -1.23 & 1.20 & 2 & Coca & grass & Coca & grass & juvenile & $\begin{array}{l}\text { total biomass } \\
\text { aboveground }\end{array}$ & 0.01 & 0.14 \\
\hline G & 35 & [13] & 26.13 & -81.78 & 0.84 & 4 & Unpa & grass & Unpa & grass & juvenile & $\begin{array}{c}\text { biomass } \\
\text { aboveground }\end{array}$ & 1.41 & 1.56 \\
\hline G & 36 & [13] & 26.13 & -81.78 & 0.84 & 4 & Ivim & shrub & Unpa & grass & juvenile & $\begin{array}{c}\text { biomass } \\
\text { aboveground }\end{array}$ & 0.95 & 1.91 \\
\hline G & 37 & [13] & 26.13 & -81.78 & 0.84 & 4 & Unpa & grass & Unpa & grass & juvenile & $\begin{array}{c}\text { biomass } \\
\text { aboveground }\end{array}$ & -2.14 & 1.74 \\
\hline $\mathrm{G}$ & 38 & [13] & 26.13 & -81.78 & 0.84 & 4 & Ivim & shrub & Unpa & grass & juvenile & biomass & -2.71 & 2.33 \\
\hline G & 39 & [13] & 26.13 & -81.78 & 0.84 & 4 & Unpa & grass & Ivim & shrub & juvenile & leaf number & -0.01 & 0.70 \\
\hline $\mathrm{G}$ & 40 & [13] & 26.13 & -81.78 & 0.84 & 4 & Ivim & shrub & Ivim & shrub & juvenile & leaf number & 0.60 & 1.36 \\
\hline G & 41 & [13] & 26.13 & -81.78 & 0.84 & 4 & Unpa & grass & Ivim & shrub & juvenile & leaf number & -1.43 & 0.39 \\
\hline G & 42 & {$[13]$} & 26.13 & -81.78 & 0.84 & 4 & Ivim & shrub & Ivim & shrub & juvenile & leaf number & -1.67 & 0.50 \\
\hline G & 43 & {$[14]$} & 55.28 & -77.75 & 1.43 & 1 & Hope & forb & Lemo & grass & seedling & $\begin{array}{l}\text { total biomass } \\
\text { increment in }\end{array}$ & -0.09 & 0.04 \\
\hline G & 44 & {$[23]$} & 37.20 & -7.11 & 0.44 & 2 & Remo & shrub & Thca & shrub & adult & $\begin{array}{l}\text { canopy area } \\
\text { increment in }\end{array}$ & 0.44 & 0.21 \\
\hline $\mathrm{G}$ & 45 & {$[23]$} & 37.20 & -7.11 & 0.44 & 2 & Remo & shrub & Thca & shrub & adult & canopy area & -0.98 & 0.32 \\
\hline $\mathrm{G}$ & 46 & {$[25]$} & 38.32 & -123.06 & 0.94 & 2 & Bapi & shrub & Luar & shrub & seedling & height & 0.51 & 0.05 \\
\hline G & 47 & {$[25]$} & 38.32 & -123.06 & 0.94 & 2 & Amar & grass & Luar & shrub & seedling & height & 0.81 & 0.09 \\
\hline G & 48 & [26] & 41.90 & -69.96 & 1.45 & 2 & Mype & shrub & Sose & forb & seedling & total biomass & 1.58 & 0.28 \\
\hline G & 49 & {$[26]$} & 41.90 & -69.96 & 1.45 & 2 & Mype & shrub & Ambr & grass & adult & total biomass & 1.70 & 0.29 \\
\hline $\mathrm{G}$ & 50 & [26] & 41.90 & -69.96 & 1.45 & 2 & Mype & shrub & Sose & forb & adult & total biomass & 1.44 & 0.33 \\
\hline $\mathrm{R}$ & 1 & {$[1]$} & 36.68 & -2.70 & 0.23 & 2 & NI & shrub & Juph & shrub & adult & fruit number & -0.95 & 0.25 \\
\hline $\mathrm{R}$ & 2 & {$[1]$} & 36.68 & -2.70 & 0.23 & 2 & $\mathrm{NI}$ & shrub & Pile & shrub & adult & fruit number & 0.25 & 0.22 \\
\hline
\end{tabular}


Table S1 (cont.)

\begin{tabular}{|c|c|c|c|c|c|c|c|c|c|c|c|c|c|c|}
\hline \multirow[b]{2}{*}{ TPV } & \multirow[b]{2}{*}{ ES } & \multirow[b]{2}{*}{ Pub } & \multirow[b]{2}{*}{ Lat } & \multirow[b]{2}{*}{ Lon } & \multirow[b]{2}{*}{ GAI } & \multirow[b]{2}{*}{ Grad } & \multicolumn{2}{|c|}{ Neighbor } & \multicolumn{3}{|c|}{ Target } & \multirow[b]{2}{*}{ OPV } & \multirow[b]{2}{*}{ Hedge's d } & \multirow[b]{2}{*}{ Var } \\
\hline & & & & & & & Species & Life-form & Species & Life-form & $\begin{array}{c}\text { Ontogenetic } \\
\text { stage }\end{array}$ & & & \\
\hline $\mathrm{R}$ & 3 & [4] & 40.56 & -74.09 & 1.18 & 1 & Ambr & grass & Trpu & grass & several & seed number & -0.44 & 0.01 \\
\hline $\mathrm{R}$ & 4 & [4] & 40.56 & -74.09 & 1.18 & 1 & Ambr & grass & Cetr & grass & several & seed number & 0.07 & 0.01 \\
\hline $\mathrm{R}$ & 5 & {$[4]$} & 40.56 & -74.09 & 1.18 & 1 & Ambr & grass & Hesu & forb & several & $\begin{array}{l}\text { seed number } \\
\text { spikelets per }\end{array}$ & -0.15 & 0.08 \\
\hline $\mathrm{R}$ & 6 & {$[6]$} & 38.31 & -123.05 & 0.91 & 2 & Amar & grass & Ehca & grass & adult & $\begin{array}{l}\text { plant } \\
\text { spikelets per }\end{array}$ & 0.64 & 0.21 \\
\hline $\mathrm{R}$ & 7 & [6] & 38.31 & -123.05 & 0.91 & 2 & Bapi & shrub & Ehca & grass & adult & $\begin{array}{l}\text { plant } \\
\text { spikelets per }\end{array}$ & 1.19 & 0.24 \\
\hline $\mathrm{R}$ & 8 & {$[6]$} & 38.31 & -123.05 & 0.91 & 2 & Caed & forb & Ehca & grass & adult & $\begin{array}{l}\text { plant } \\
\text { branches with }\end{array}$ & 0.65 & 0.21 \\
\hline $\mathrm{R}$ & 9 & {$[8]$} & 34.68 & -120.60 & 0.32 & 2 & Caed & forb & Isme & shrub & adult & flowers (\%) & 1.59 & 0.41 \\
\hline $\mathrm{R}$ & 10 & {$[11]$} & 39.73 & 8.66 & 0.53 & 2 & NI & shrub & Dimo & sub shrub & adult & $\begin{array}{l}\text { flower number } \\
\text { spikelets per }\end{array}$ & 0.53 & 0.06 \\
\hline $\mathrm{R}$ & 11 & {$[17]$} & 38.31 & -123.05 & 0.91 & 2 & Erer & shrub & Brdi & grass & adult & $\begin{array}{l}\text { plant } \\
\text { reproductive }\end{array}$ & 0.55 & 0.07 \\
\hline $\mathrm{R}$ & 12 & [19] & 39.75 & -74.10 & 1.15 & 1 & Ambr & grass & Sose & forb & adult & $\begin{array}{l}\text { biomass } \\
\text { flowering }\end{array}$ & -0.72 & 0.09 \\
\hline $\mathrm{R}$ & 13 & [26] & 41.90 & -69.96 & 1.45 & 2 & Mype & shrub & Ambr & grass & adult & $\begin{array}{l}\text { stems density } \\
\text { flowering }\end{array}$ & 1.20 & 0.12 \\
\hline $\mathrm{R}$ & 14 & [26] & 41.90 & -69.96 & 1.45 & 2 & Mype & shrub & Sose & forb & adult & stems density & 1.02 & 0.11 \\
\hline $\mathrm{R}$ & 15 & [26] & 41.90 & -69.96 & 1.45 & 2 & Mype & shrub & Ambr & grass & adult & flower number & 2.85 & 0.45 \\
\hline $\mathrm{R}$ & 16 & [26] & 41.90 & -69.96 & 1.45 & 2 & Mype & shrub & Sose & forb & adult & flower number & 1.43 & 0.26 \\
\hline
\end{tabular}


Table S2. List of species included in meta-analyses. Species: accepted species name according to The Plant List (2018). Code: code used to identify species in analysis (first two letters of genus followed by the first two letters of specific epithet). Synoym: species names as presented in original publication.

\begin{tabular}{|c|c|c|c|}
\hline Species & Code & Family & Synonym \\
\hline Acacia saligna & Acsa & Fabaceae & \\
\hline Aegilops bicornis & Aebi & Poaceae & \\
\hline Alhagi graecorum & Algr & Fabaceae & \\
\hline Ammophila arenaria & Amar & Poaceae & \\
\hline Ammophila breviligulata & Ambr & Poaceae & \\
\hline Anagallis arvensis & Anar & Primulaceae & \\
\hline Anchusa humilis & Anhu & Boraginaceae & \\
\hline Arenaria serpyllifolia subsp. leptoclados & Arse & Caryophyllaceae & Arenaria leptocladus [28] \\
\hline Armeria pungens & Arpu & Plumbaginaceae & \\
\hline Arthrocnemum macrostachyum & Arma & Amaranthaceae & \\
\hline Astragalus hispidulus & Ashi & Fabaceae & \\
\hline Avena fatua & Avfa & Poaceae & Baccharis pilularis pilularis [25] \\
\hline Baccharis pilularis & Bapi & Asteraceae & \\
\hline Bassia indica & Bain & Amaranthaceae & \\
\hline Beta vulgaris & Bevu & Amaranthaceae & Beta vulgaris var. cicla $[10]$ \\
\hline Brassica tournefortii & Brto & Brassicaceae & \\
\hline Bromus diandrus & Brdi & Poaceae & \\
\hline Cakile maritima & Cama & Brassicaceae & Cakile maritime subsp. aegyptiaca $[10]$ \\
\hline Carduus pycnocephalus & Capy & Asteraceae & \\
\hline Carpobrotus acinaciformis & Caac & Aizoaceae & \\
\hline Carpobrotus edulis & Caed & Aizoaceae & \\
\hline Carthamus tenuis & Cate & Asteraceae & \\
\hline Cenchrus tribuloides & Cetr & Poaceae & \\
\hline Chamaecrista chamaecristoides & Chch & Fabaceae & Chamaecrista chamaecristoides var. chamaecristoides [21] \\
\hline Chenopodium murale & Chmu & Amaranthaceae & \\
\hline
\end{tabular}


Table S2 (cont.).

\begin{tabular}{|c|c|c|c|}
\hline Species & Code & Family & Synonym \\
\hline Cistus salviifolius & Cisa & Cistaceae & \\
\hline Claytonia perfoliata & Clpe & Montiaceae & \\
\hline Corynephorus canescens & Coca & Poaceae & \\
\hline Crepis aculeata & Crac & Asteraceae & \\
\hline Cutandia memphitica & Cume & Poaceae & \\
\hline Cynodon dactylon & Cyda & Poaceae & \\
\hline Cyperus capitatus & Cyca & Cyperaceae & \\
\hline Daphne gnidium & Dagn & Thymelaeaceae & \\
\hline Daucus littoralis & Dali & Apiaceae & \\
\hline Desmazeria philistaea & Deph & Poaceae & Cutandia philastaea [28] \\
\hline Dianthus morisianus & Dimo & Caryophyllaceae & \\
\hline Echinops spinosissimus & Ecsp & Asteraceae & Echinops spinosus $[10]$ \\
\hline Echium angustifolium subsp. sericeum & Ecan & Boraginaceae & \\
\hline Ehrharta calycina & Ehca & Poaceae & \\
\hline Elymus farctus & Elfa & Poaceae & \\
\hline Emex spinosa & Emsp & Polygonaceae & \\
\hline Empetrum nigrum subsp. hermaphroditum & Emni & Ericaceae & Empetrum nigrum ssp. hermaphroditum [15] \\
\hline Erica multiflora & Ermu & Ericaceae & \\
\hline Ericameria ericoides & Erer & Asteraceae & Haplopappus ericoides [8] \\
\hline Erodium laciniatum & Erla & Geraniaceae & \\
\hline Festuca vasconcensis & Feva & Poaceae & \\
\hline Fumaria judaica & Fuju & Papaveraceae & Fumaria jewdica [28] \\
\hline Guapira opposita & Guop & Nyctaginaceae & \\
\hline Halocnemum strobilaceum & Hast & Amaranthaceae & \\
\hline Helichrysum stoechas & Hest & Asteraceae & \\
\hline Heterotheca subaxillaris & Hesu & Asteraceae & \\
\hline
\end{tabular}


Table S2 (cont.).

\begin{tabular}{|c|c|c|c|}
\hline Species & Code & Family & Synonym \\
\hline Honckenya peploides & Hope & Caryophyllaceae & \\
\hline Hordeum murinum subsp. leporinum & Homu & Poaceae & \\
\hline Ifloga spicata & Ifsp & Asteraceae & \\
\hline Isocoma menziesii var. sedoides & Isme & Asteraceae & Haplopappus venetus var. sedoides [8] \\
\hline Iva imbricata & Ivim & Asteraceae & \\
\hline Juniperus phoenicea var. turbinata & Juph & Cupressaceae & Juniperus phoenicea subsp. turbinata [1] \\
\hline Juniperus virginiana & Juvi & Cupressaceae & \\
\hline Launaea mucronata & Lamu & Asteraceae & \\
\hline Lepidium sativum & Lesa & Brassicaceae & \\
\hline Leymus mollis & Lemo & Poaceae & \\
\hline Lolium perenne & Lope & Poaceae & \\
\hline Lophochloa pubescens & Lopu & Poaceae & \\
\hline Lotus creticus & Locr & Fabaceae & \\
\hline Lotus cytisoides & Locy & Fabaceae & \\
\hline Lotus halophilus & Loha & Fabaceae & \\
\hline Lupinus arboreus & Luar & Fabaceae & \\
\hline Lupinus chamissonis & Luch & Fabaceae & \\
\hline Malva parviflora & Mapa & Malvaceae & \\
\hline Maresia pulchella & Mapu & Brassicaceae & \\
\hline Medicago intertexta subsp. ciliaris & Mein1 & Fabaceae & Medicago intertexta var. ciliaris [10] \\
\hline Medicago marina & Mema & Fabaceae & \\
\hline Melilotus indicus & Mein2 & Fabaceae & \\
\hline Mesembryanthemum crystallinum & Mecr & Aizoaceae & \\
\hline Mesembryanthemum nodiflorum & Meno & Aizoaceae & \\
\hline Moltkiopsis ciliata & Moci & Boraginaceae & \\
\hline Myrica pensylvanica & Mype & Myricaceae & \\
\hline Oenothera biennis & Oebi & Onagraceae & \\
\hline
\end{tabular}


Table S2 (cont.).

\begin{tabular}{|c|c|c|c|}
\hline Species & Code & Family & Synonym \\
\hline Ononis serrata & Onse & Fabaceae & \\
\hline Pancratium maritimum & Pama & Amaryllidaceae & \\
\hline Paspalidium geminatum & Page & Poaceae & \\
\hline Pinus halepensis & Piha & Pinaceae & \\
\hline Pinus sylvestris & Pisy & Pinaceae & \\
\hline Pistacia lentiscus & Pile & Anacardiaceae & \\
\hline Plantago indica & Plin & Plantaginaceae & Plantago psyllium [28] \\
\hline Plantago squarrosa & Plsq & Plantaginaceae & \\
\hline Polycarpon succulentum & Posu & Caryophyllaceae & \\
\hline Polygonum equisetiforme & Poeq & Polygonaceae & \\
\hline Polypogon monspeliensis & Pomo & Poaceae & \\
\hline Prunus serotina & Prse & Rosaceae & \\
\hline Quercus ilex & Quil & Fagaceae & \\
\hline Quercus robur & Quro & Fagaceae & \\
\hline Quercus suber & Qusu & Fagaceae & \\
\hline Reichardia tingitana & Reti & Asteraceae & \\
\hline Retama monosperma & Remo & Fabaceae & \\
\hline Retama raetam & Rera & Fabaceae & \\
\hline Rumex bucephalophorus & Rubu & Polygonaceae & \\
\hline Rumex pictus & Rupi & Polygonaceae & \\
\hline Salsola kali & Saka & Amaranthaceae & \\
\hline Sassafras albidum & Saal & Lauraceae & \\
\hline Schizachyrium scoparium & Scsc & Poaceae & Schizachyrium scoparium var. littoralis [21] \\
\hline Senecio glaucus & Segl & Asteraceae & \\
\hline Senecio inaequidens & Sein & Asteraceae & \\
\hline Silene succulenta & Sisu & Caryophyllaceae & \\
\hline Solidago sempervirens & Sose & Asteraceae & \\
\hline
\end{tabular}


Table S2 (cont.).

\begin{tabular}{llll}
\hline Species & Code & Family & Synonym \\
\hline Sonchus oleraceus & Sool & Asteraceae & \\
Spergularia marina & Spma & Caryophyllaceae & \\
Tamarix senegalensis & Tase & Tamaricaceae & Tamarix nilotica $[10]$ \\
Ternstroemia brasiliensis & Tebr & Pentaphylacaceae & \\
Tetraena alba & Teal & Zygophyllaceae & Zygophyllum album [10] \\
Thymus carnosus & Thca & Lamiaceae & \\
Trachypogon spicatus & Trsp & Poaceae & Trachypogon plumosus $[21]$ \\
Trifolium palaestinum & Trpa & Fabaceae & \\
Triplasis purpurea & Trpu & Poaceae & \\
Uniola paniculata & Unpa & Poaceae & \\
Urospermum picroides & Urpi & Asteraceae & \\
Valantia hispida & Vahi & Rubiaceae & \\
Vulpia bromoides & Vubr & Poaceae & \\
Zygophyllum aegyptium & Zyae & Zygophyllaceae & Tetraena aegyptia $[10]$ \\
not informed & NI & NA & \\
\hline
\end{tabular}

\section{References}

The Plant List (2018). Version 1.1. Published on the Internet; http://www.theplantlist.org/ (last accessed 23th May). 
Appendix S1. References of publications eligible for meta-analysis.

\section{Publications included in meta-analysis and cited in tables S1 and S2}

[1] Armas, C. \& Pugnaire, F.I. 2009. Ontogenetic shifts in interactions of two dominant shrub species in a semi-arid coastal sand dune system. Journal of Vegetation Science 20: 535-546.

[2] Bonanomi, G., Rietkerk, M., Dekker, S.C. \& Mazzoleni, S. 2008. Islands of fertility induce co-occurring negative and positive plant-soil feedbacks promoting coexistence. Plant Ecology 197: $207-218$.

[3] Castanho, C.T. \& Prado, P.I. 2014. Benefit of shading by nurse plant does not change along a stress gradient in a coastal dune. PLOS ONE 9: e105082.

[4] Cheplick, G.P. 2005. Patterns in the distribution of American beachgrass (Ammophila breviligulata) and the density and reproduction of annual plants on a coastal beach. Plant Ecology 180: $57-67$.

[5] Cushman, J.H., Jeffrey, C.W. \& Derek, R.H. 2010. Shrubs as ecosystem engineers in a coastal dune: influences on plant populations, communities and ecosystems. Journal of Vegetation Science 21: 821-831.

[6] Cushman, J.H., Lortie, C.J. \& Christian, C.E. 2011. Native herbivores and plant facilitation mediate the performance and distribution of an invasive exotic grass. Journal of Ecology 99 : 524-531.

[7] Cusseddu, V., Ceccherelli, G. \& Bertness, M. 2016. Hierarchical organization of a Sardinian sand dune plant community. PeerJ 4: e2199.

[8] D'Antonio, C.M. \& Mahall, B.E. 1991. Root profiles and competition between the invasive, exotic perennial, Carpobrotus edulis, and two native shrub species in California coastal scrub. American Journal of Botany 78: 885-894.

[9] D'Antonio, C.M. 1993. Mechanisms controlling invasion of coastal plant communities by the alien succulent Carpobrotus edulis. Ecology 74: 83-95.

[10] El-Gawad, A.A. \& El-Amier, Y. 2015. Allelopathy and potential impact of invasive Acacia saligna (Labill.) Wendl. on plant diversity in the Nile delta coast of Egypt. International Journal of Environmental Research 9: 923-932.

[11] Fenu, G., Cogoni, D., Navarro, F.B., Concas, E. \& Bacchetta, G. 2017. The importance of the Cisto-Lavanduletalia coastal habitat on population persistence of the narrow endemic Dianthus morisianus (Caryophyllaceae). Plant Species Biology 32: 156-168. 
[12] Forey, E., Touzard, B. \& Michalet, R. 2010. Does disturbance drive the collapse of biotic interactions at the severe end of a diversity-biomass gradient? Plant Ecology 206: 287-295.

[13] Franks, S.J. 2003a. Competitive and facilitative interactions within and between two species of coastal dune perennials. Canadian Journal of Botany 81: 330-337.

[14] Gagné, J.-M. \& Houle, G. 2001. Facilitation of Leymus mollis by Honckenya peploides on coastal dunes in subarctic Quebec, Canada. Canadian Journal of Botany 79: 1327-1331.

[15] Grau, O., Rautio, P., Heikkinen, J., Saravesi, K., Kozlov, M.V. \& Markkola, A. 2010. An ericoid shrub plays a dual role in recruiting both pines and their fungal symbionts along primary succession gradients. Oikos 119: 1727-1734.

[16] Joy, D.A. \& Young, D.R. 2002. Promotion of mid-successional seedling recruitment and establishment by Juniperus virginiana in a coastal environment. Plant Ecology 160: 125-135.

[17] Kleinhesselink, A.R., Magnoli, S.M. \& Cushman, J.H. 2014. Shrubs as ecosystem engineers across an environmental gradient: effects on species richness and exotic plant invasion. Oecologia 175: 1277-1290.

[18] Le Bagousse-Pinguet, Y., Forey, E., Touzard, B. \& Michalet, R. 2013. Disentangling the effects of water and nutrients for studying the outcome of plant interactions in sand dune ecosystems. Journal of Vegetation Science 24: 375-383.

[19] Lee, P.C. 1995. The effect of gap dynamics on the size and spatial structure of Solidago sempervirens on primary coastal dunes. Journal of Vegetation Science 6: 837-846.

[20] Martínez, M.L. 2003. Facilitation of seedling establishment by an endemic shrub in tropical coastal sand dunes. Plant Ecology 168: 333-345.

[21] Martínez, M.L., Pérez-Maqueo, O. \& Vásquez, V.M. 2004. Facilitative interactions on coastal dunes in response to seasonal weather fluctuations and benefactor size. Écoscience 11: 390-398.

[22] Muhamed, H., Maalouf, J.P. \& Michalet, R. 2013. Summer drought and canopy opening increase the strength of the oak seedlings-shrub spatial association. Annals of Forest Science 70: 345-355.

[23] Paz-Esquivias, M., Zunzunegui, M., Díaz Barradas, M.C. \& Álvarez-Cansino, L. 2015. Competitive effect of a native-invasive species on a threatened shrub in a Mediterranean dune system. Oecologia 177: 133-146.

[24] Rodríguez-Pérez, J. \& Traveset, A. 2007. A multi-scale approach in the study of plant regeneration: Finding bottlenecks is not enough. Perspectives in Plant Ecology, Evolution and Systematics 9: 1-13. 
[25] Rudgers, J.A. \& Maron, J.L. 2003. Facilitation between coastal dune shrubs: a non-nitrogen fixing shrub facilitates establishment of a nitrogen-fixer. Oikos 102: 75-84.

[26] Shumway, S.W. 2000. Facilitative effects of a sand dune shrub on species growing beneath the shrub canopy. Oecologia 124: 138-148.

[27] Sternberg, M., Yu, S.L. \& Bar, P. 2004. Soil seed banks, habitat heterogeneity, and regeneration strategies in a Mediterranean coastal sand dune. Israel Journal of Plant Sciences 52: $213-221$.

[28] Yu, S., Bell, D. \& Kutiel, P.B. 2009. Impact of microhabitats on the heterogeneity of seedling emergence in a Mediterranean coastal sand dunes community. Écoscience 16: 369-378.

\section{Publications not included in meta-analysis due to small number of studies or outcomes}

Cervera, J.C., Andrade, J.L., Simá, J.L. \& Graham, E.A. 2006. Microhabitats, germination, and establishment for Mammillaria gaumeri (Cactaceae), a rare species from Yucatan. International Journal of Plant Sciences 167: 311-319.

Franks, S.J. 2003b. Facilitation in multiple life-history stages: evidence for nucleated succession in coastal dunes. Plant Ecology 168: 1-11.

Castanho, C.T., Oliveira, A.A. \& Prado, P.I. 2012. The importance of plant life form on spatial associations along a subtropical coastal dune gradient. Journal of Vegetation Science 23: 952961. 
Table S3. Total heterogeneity among data and heterogeneity associated to random factors for each performance variable, considering an overall model and models for environmental conditions (GAI models) and for plant features. A: abundance; S: survival; G: growth; R: reproduction.

$\begin{array}{llll}\mathbf{A} & \mathbf{S} & \mathbf{G} & \mathbf{R}\end{array}$

\section{TOTAL}

Overall (without moderators)

$\begin{array}{llll}96.16 & 70.54 & 83.96 & 85.61\end{array}$

GAI model

96.12

73.32

84.35

92.46

Plants features model

96.31

60.32

82.13

78.07

\section{RANDOM FACTORS}

\section{Study identity}

GAI model

Plants features model

\section{Neighbor species}

GAI model

Plants features model

Target species

GAI model

Plants features model
$6.12 \times 10^{-8}$

54.14

0.04

92.46

$4.17 \times 10^{-8}$

45.76

3.72

$6.76 \times 10^{-7}$

70.47

10.48

50.19

$2.62 \times 10^{-9}$

70.42

6.71

63.00

21.22 
Table S4. Publication bias in data for each performance variable, considering models for environmental conditions (GAI models) and for plant features. ES: effect size. FSN: fail safe number.

\begin{tabular}{|c|c|c|c|c|c|c|}
\hline & & \multicolumn{2}{|c|}{ Egger's regression } & \multicolumn{3}{|c|}{ Orwin's number } \\
\hline & & Intercept & p-value & Average ES & Target ES & FSN \\
\hline \multirow{2}{*}{ Abundance } & GAI model & 0.688 & $3.45 \times 10^{-4}$ & \multirow{2}{*}{-0.3723} & \multirow{2}{*}{-0.05} & \multirow{2}{*}{671} \\
\hline & Plant features model & 0.3409 & 0.071 & & & \\
\hline \multirow{2}{*}{ Survival } & GAI model & -0.039 & 0.830 & \multirow{2}{*}{0.455} & \multirow{2}{*}{0.05} & \multirow{2}{*}{528} \\
\hline & Plant features model & 0.021 & 0.912 & & & \\
\hline \multirow{2}{*}{ Growth } & GAI model & 0.056 & 0.804 & \multirow{2}{*}{0.144} & \multirow{2}{*}{0.05} & \multirow{2}{*}{94} \\
\hline & Plant features model & -0.1160 & 0.596 & & & \\
\hline \multirow{2}{*}{ Reproduction } & GAI model & -0.570 & 0.03 & \multirow{2}{*}{0.608} & \multirow{2}{*}{0.05} & \multirow{2}{*}{179} \\
\hline & Plant features model & -0.2820 & 0.297 & & & \\
\hline
\end{tabular}




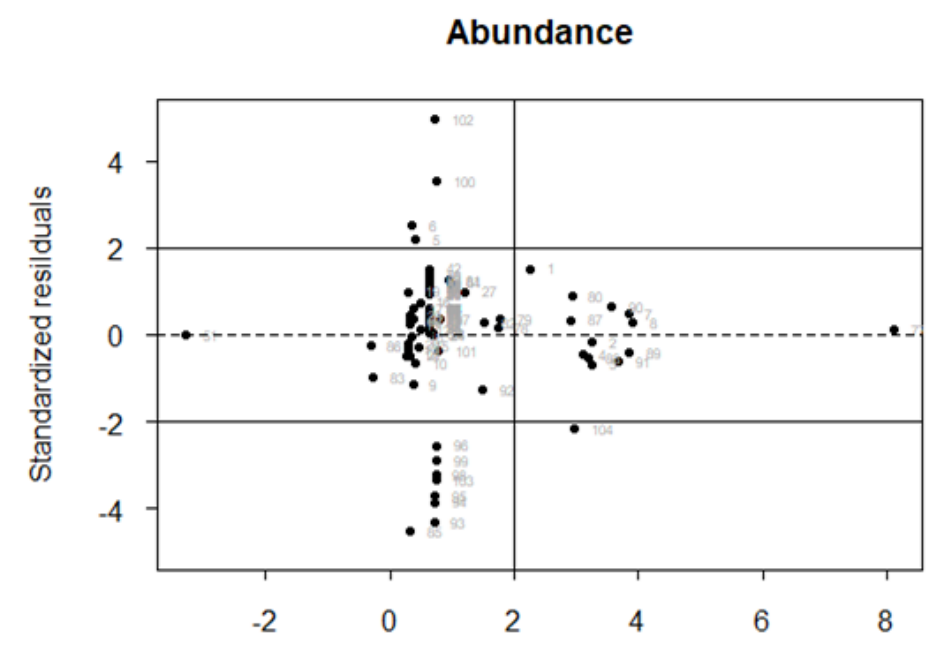

Growth

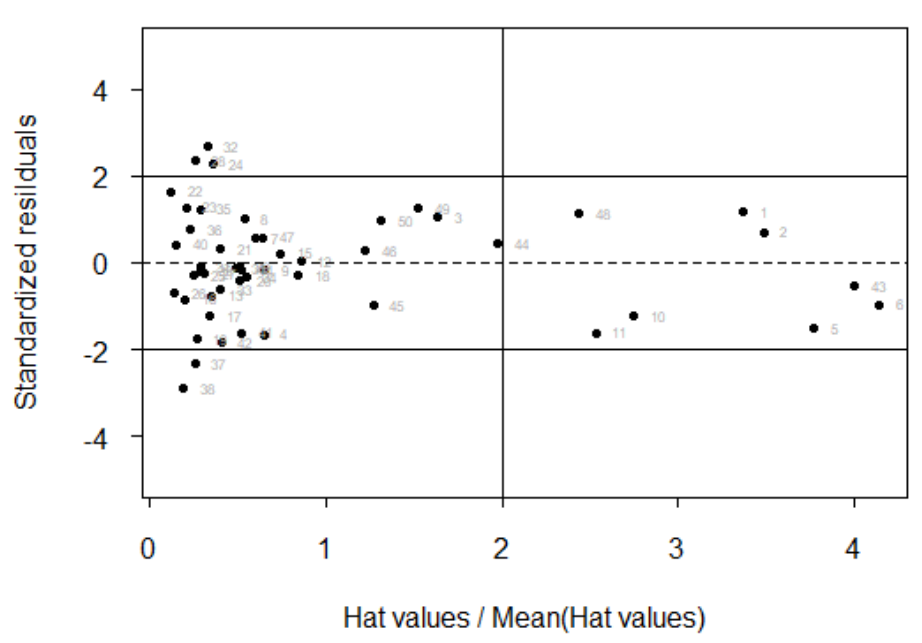

Survival

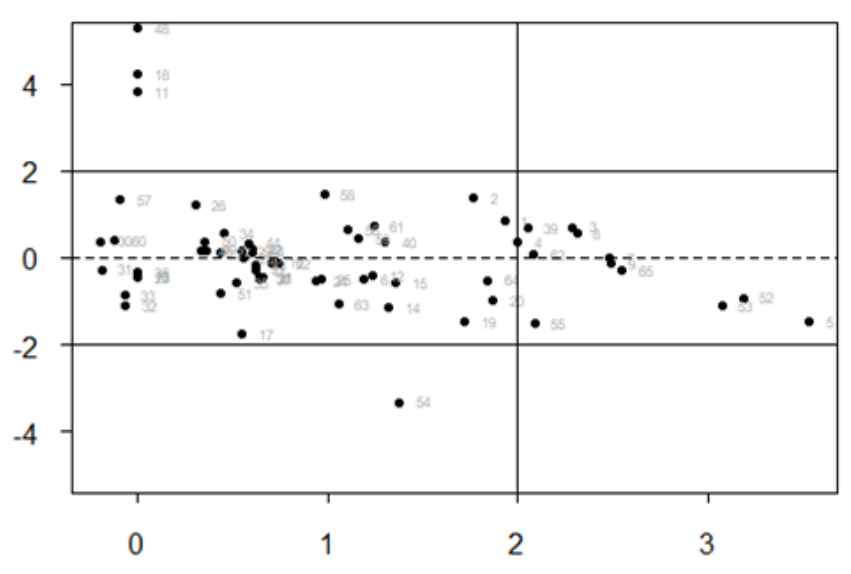

Reproduction

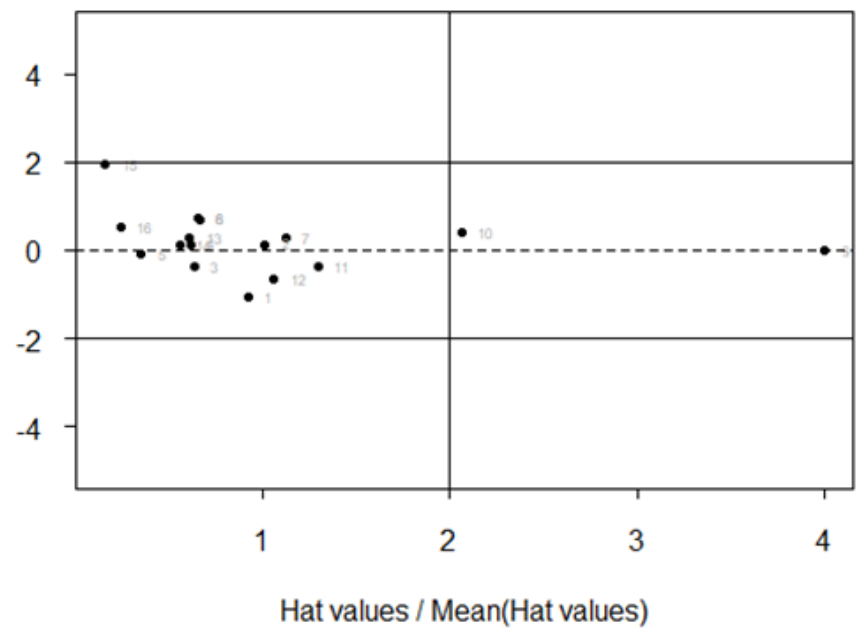

Figure S1. Sensitivity plots of environmental conditions models for each performance variable. Influential outliers are those with standardized residual values exceeding 2.0 and hat values greater than two times the average hat value. 


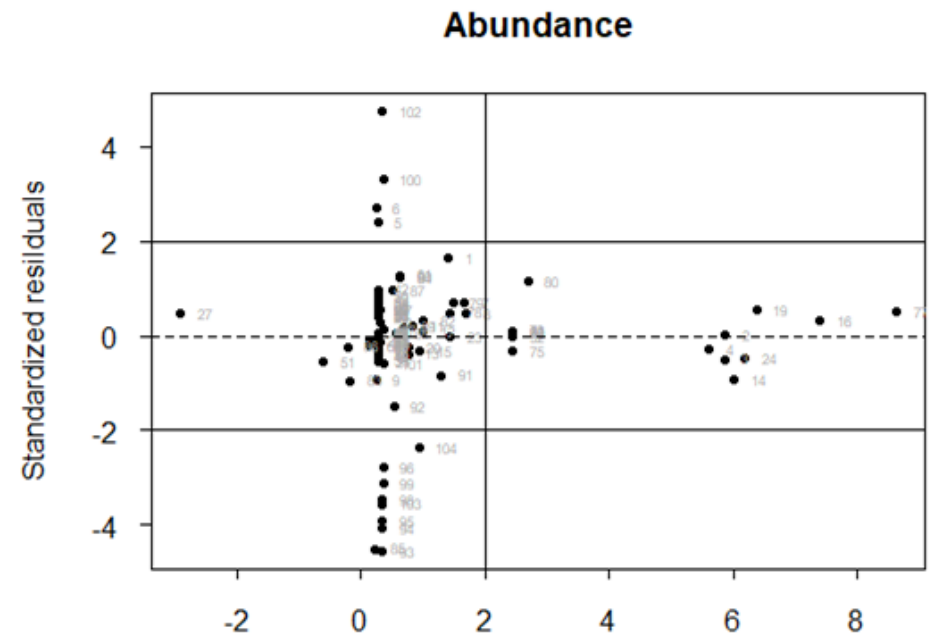

Growth

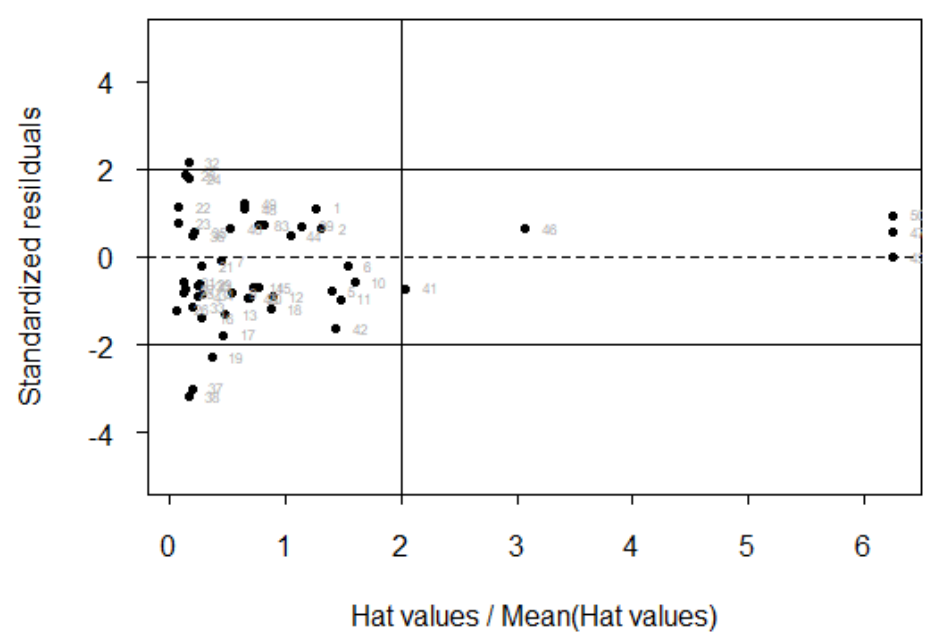

Survival

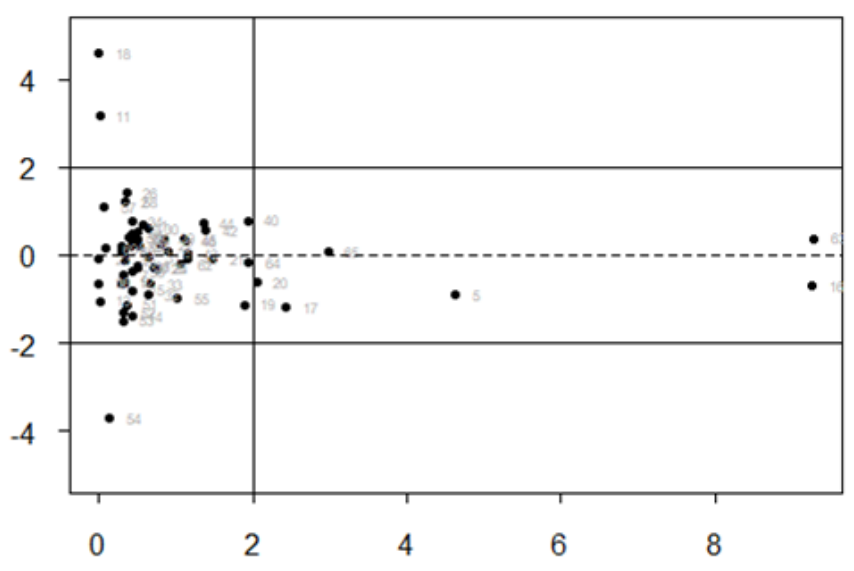

Reproduction

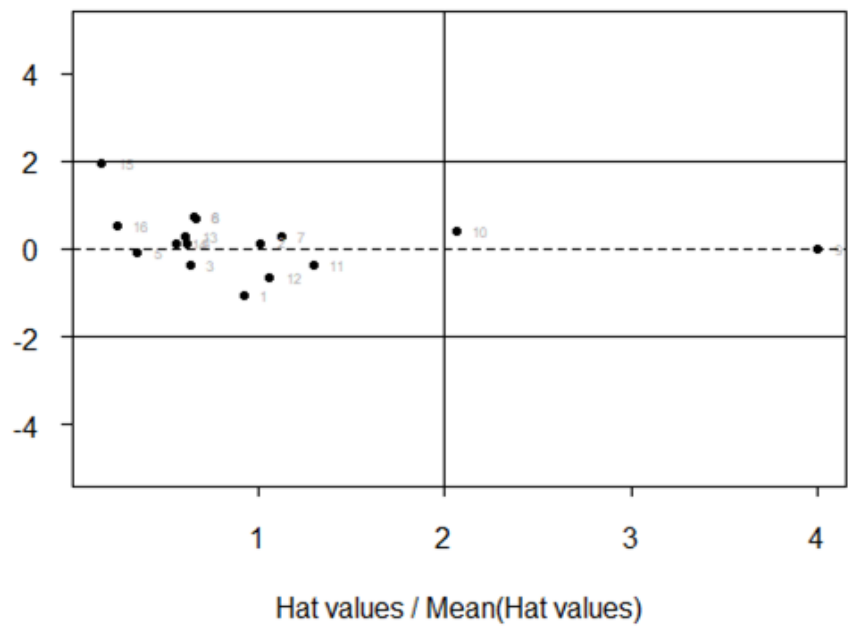

Figure S2. Sensitivity plots of plant features models for each performance variable. Influential outliers are those with standardized residual values exceeding 2.0 and hat values greater than two times the average hat value. 
Survival

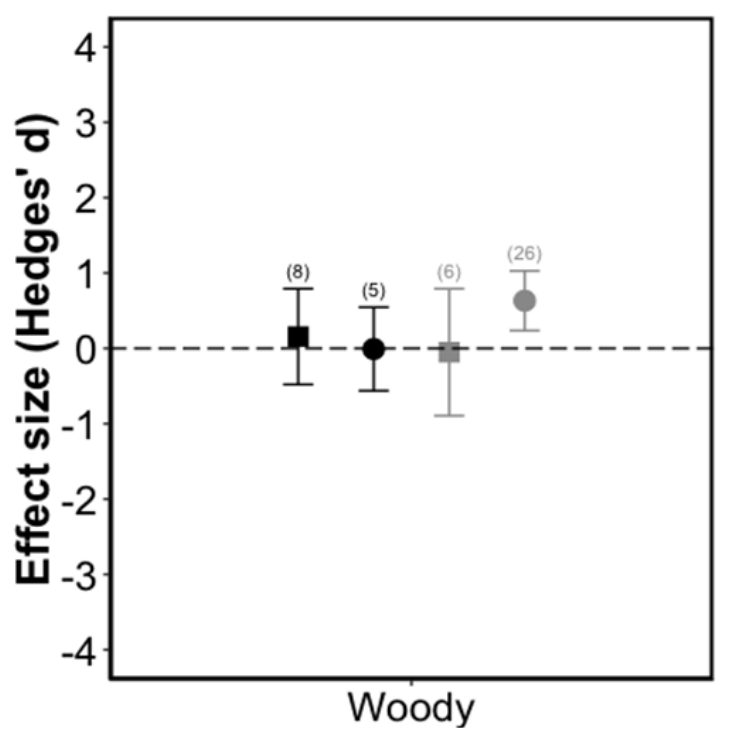

Reproduction

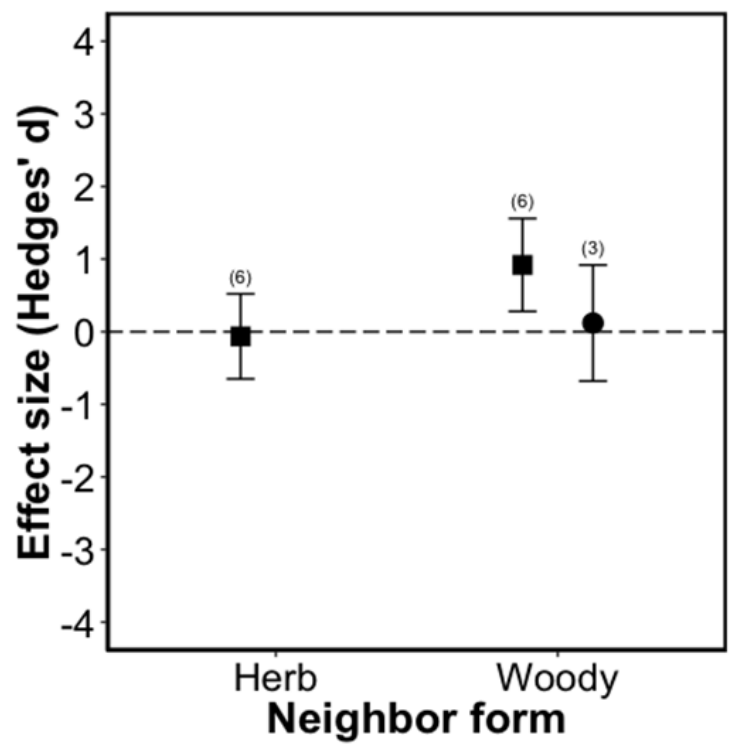

Growth

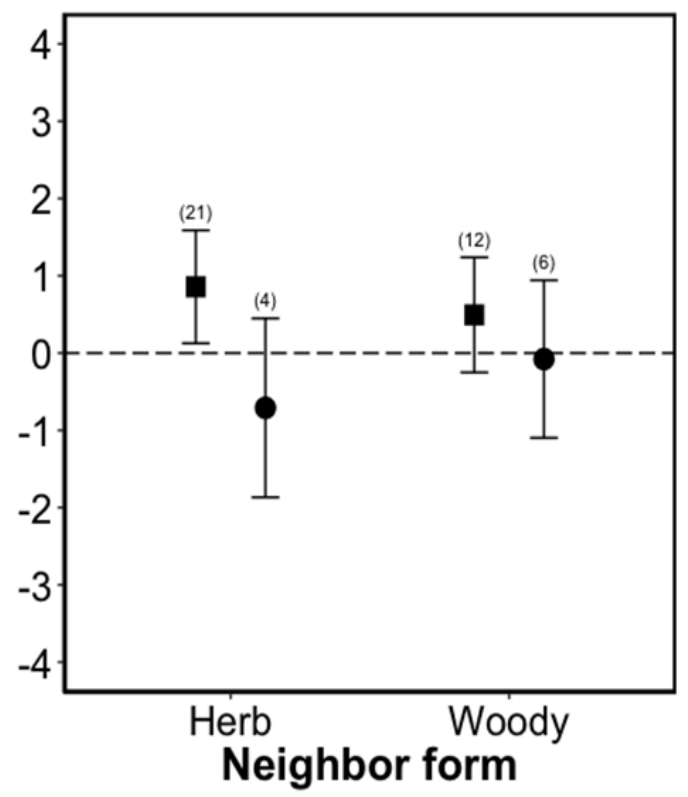

Target form

Herb

- Woody

Target stage

- Not seedling

- Seedling

Figure S3. Predicted net outcome of interactions for combinations of plant life form and ontogenetic stage in sandy coastal dunes, for each performance variable. Net outcome of interaction is presented as Hedges'd, with positive values indicating facilitation and negative values indicating competition. Vertical bars represent $95 \%$ confidence interval. Numbers above bars represent the number of outcomes in the respective combination. We excluded all combinations of plant features with less than three outcomes. For survival, we excluded all data from herbaceous neighbors. For growth, we excluded all data from seedling targets. For reproduction, the combination of herb neighbor and woody target were excluded. 